\title{
Notes
}

\section{The Miscegenation Analogy: Sodomy Law as Sex Discrimination}

\section{Andrew Koppelman}

The gay rights question has become a chronic irritant in constitutional law. For more than twenty years, commentators ${ }^{1}$ and courts $^{2}$ have debated whether state action that imposes special burdens on homosexuals violates the Constitution. The Supreme Court's opinion in Bowers v. Hardwick, ${ }^{3}$ which upheld the constitutionality of criminal prohibitions of sodomy, has exacerbated the controversy rather than resolving it. The present state of confusion should trouble not only constitutional lawyers, ${ }^{4}$ but all Americans.

At the center of the debate is the constitutionality of the sodomy statutes. While enforcement of these laws is sporadic at best, this is as poor a measure of the injury they inflict as the relative infrequency of lynching in the post-Civil War South. By branding all gays as criminals, the sodomy prohibition provides a justification for other forms of discrimination, public and private, which injure gays in such areas as employment, professional licensing, free speech, immigration, adoption, and child custody. ${ }^{5}$

1. See Brest, The Fundamental Rights Controversy: The Essential Contradictions of Normative Constitutional Scholarship, 90 YALE L.J. 1063 (1981), and citations therein.

2. See Annotation, Validity of Statute Making Sodomy a Criminal Offense, 20 A.L.R.4th 1009 (1983 \& Supp. 1988) (collecting cases).

3. 478 U.S. 186 (1986).

4. One of whom concluded, after surveying the arguments, that "no defensible criteria [for resolving such disputes about fundamental rights] exist." Brest, supra note 1, at 1065.

5. See Brief of Amicus Lesbian Rights Project at 21-24, Bowers (No. 85-140); Brief of Amicus Lambda Legal Defense and Educational Fund at 25-30, Bowers, and citations therein. Like heterosexuals, not all homosexuals engage in sexual intercourse. But courts have frequently overlooked this fact, invoking the sodomy statutes to justify a broad range of discriminations against gays without requiring evidence that the particular party before them had violated any law. Id. 
Perhaps equally significant is the sheer insult that the statutes impose. As Richard Mohr observes, "unenforced sodomy laws are the chief systematic way that society as a whole tells gays they are scum."6

The debate over the constitutionality of these statutes has centered upon two intractable issues. First, the familiar argument that the sodomy statutes violate the constitutional right to privacy ${ }^{2}$ resists principled resolution, because the Court has never explained how it goes about determining whether any given activity is protected by that right. As Judge Bork observed, the holdings of the privacy cases "are less prescriptions of a mode of reasoning than they are conclusions about particular rights enunciated." tion of the privacy argument in Bowers. ${ }^{9}$

Second, several authors, ${ }^{10}$ with encouragement from at least two members of the Supreme Court, ${ }^{11}$ have argued that homosexuality should be a suspect classification, like race, whose use in distributing legal burdens triggers heightened judicial scrutiny under the equal protection clause of the Fourteenth Amendment. ${ }^{12}$ But while this argument has the merit of reflecting social reality-like blacks, gays have historically been politically powerless and subject to pervasive discrimination based on prejudice-its support in existing constitutional doctrine is uncertain. This is because, once again, the Court has not explained how it determines the boundary

6. Mohr, Mr. Justice Douglas at Sodom: Gays and Privacy, 18 Colum. Hum. RTs. L. Rev. 43, 53 (1986-87).

7. The right to privacy appears to be the most frequently litigated challenge to the sodomy laws. See Annotation, supra note 2, $\$ 3$; see also Grey, Eros, Civilization and the Burger Court, 43 LAw \& Contemp. Probs., Summer 1980, at 83, 99-100 (almost all scholarly literature on privacy cases between 1965 and 1979 construed them as constitutionalizing sexual libertarianism).

8. Dronenburg v. Zech, 741 F.2d 1388, 1396 (D.C. Cir. 1984).

9. See Stoddard, Bowers v. Hardwick: Precedent by Personal Predilection, 54 U. CHI. L. Rev. 648, 652-56 (1987); Gewirtz, The Court Was 'Superficial' in the Homosexuality Case, N.Y. Times, July 8, 1986, at A21, col. 1.

10. See, e.g., Note, The Constitutional Status of Sexual Orientation: Homosexuality as a Suspect Classification, 98 Harv. L. Rev. 1285 (1985); Note, An Argument for the Application of Equal Protection Heightened Scrutiny to Classifications Based on Homosexuality, 57 S. CAL. L. REv. 797 (1984).

11. See Rowland v. Mad River Local School Dist., 470 U.S. 1009, 1014 (1985) (Brennan, J., joined by Marshall, J., dissenting from denial of cert.).

12. U.S. Const. amend. XIV, $\$ 1$ ("No State shall . . . deny to any person within its jurisdiction the equal protection of the laws."). Since Bowers, two federal courts have adopted this argument. See Watkins v. United States Army, 847 F.2d 1329, reh'g en banc ordered, 847 F.2d 1362 (9th Cir. 1988); High Tech Gays v. Defense Indus. Sec. Clearance Office, 668 F. Supp. 1361 (N.D. Cal. 1987). But see Padula v. Webster, 822 F.2d 97 (D.C. Cir. 1987); Gay \& Lesbian Students Ass'n v. Gohn, 656 F. Supp. 1045, 1056-57 (W.D. Ark. 1987), rev'd on other grounds, 850 F.2d 361 (8th Cir. 1988).

The Bowers Court considered only the privacy argument, and expressly refrained from deciding any aspect of the equal protection issue. 478 U.S. at $196 \mathrm{n.8}$; see also id. at 201 (Blackmun, J., dissenting) (noting Court's "refusal to consider" equal protection clause); Sunstein, Sexual Orientation and the Constitution: A Note on the Relationship Between Due Process and Equal Protection, 55 U. CHI. L. REv. (forthcoming 1988) (arguing that gays' equal protection claim remains persuasive even after Bowers). 
of the legal category. "The cases . . have told us that some classifications are suspect and some are not; what they do not do is tell us why." 13

In order to break this impasse, this Note will suggest a third path. ${ }^{14}$ Its argument builds upon a series of cases in which the Court has established a criterion of constitutionality which, if not a model of clarity, is at least considerably more determinate than those it has used in the areas of privacy and suspect classifications. The argument explores an analogy suggested, but not developed, in both the dissents in Bowers: the analogy between the sodomy statutes and the Jim Crow miscegenation laws, which the Court declared unconstitutional in Loving $v$. Virginia. ${ }^{15}$ The Note will conclude that sodomy and miscegenation statutes violate the equal protection clause for the same reason: Beyond the immediate harm they inflict upon their victims, their purpose is to support a regime of caste that locks some people into inferior social positions at birth. Miscegenation laws discriminated on the basis of race, and they did so in order to maintain white supremacy. Similarly, sodomy laws discriminate on the basis of sex-for example, permitting men, but not women, to have sex with women-in order to impose traditional sex roles. The Court has deemed this purpose impermissible in other contexts because it perpetuates the subordination of women. The same concern applies with special force to the sodomy laws, because their function is to maintain the polarities of gender on which the subordination of women depends. Thus, if the Court is to maintain the commitment to equality that has animated the equal protection jurisprudence of the past thirty-five years, it cannot uphold the sodomy laws and was wrong to do so in Bowers.

Part I of the Note reviews the opinions in Bowers and their discussions of the miscegenation analogy. Part II applies the precedents laid down in the Court's miscegenation decisions to demonstrate that the sodomy laws impose a sex-based classification and should therefore be subject to heightened scrutiny. Part III demonstrates that the purpose of the sodomy laws is the constitutionally impermissible one of imposing traditional sex roles. Finally, Part IV addresses the potential political difficulties that are raised by the argument's applications.

13. J. BAer, Equaltty Under the Constitution 119 (1983). See also City of Cleburne v. Cleburne Living Center, Inc., 473 U.S. 432, 460 (1985) (Marshall, J., concurring in the judgment in part and dissenting in part) ("[T] he Court provides no principled foundation for determining when more searching inquiry is to be invoked.").

14. These three alternatives do not exhaust the constitutional issues raised by anti-gay state action. Frequently, an individual is penalized for merely saying that he or she is homosexual; this raises serious First Amendment problems. See Rowland, 470 U.S. at 1011-14 (Brennan, J., joined by Marshall, J., dissenting from denial of cert.); J. Halley, The Politics of the Closet: Towards Equal Protection for Gay, Lesbian, and Bisexual Identity (1988) (draft on file with author).

15. 388 U.S. 1 (1967). 


\section{Bowers v. HaRdWICK AND the Loving ANALOgY}

In Bowers, the Supreme Court, split five to four, reversed a decision by the Eleventh Circuit that Georgia's criminalization of sodomy violated the constitutionally protected right to privacy. The Constitution, Justice White declared in the majority opinion, does not confer upon homosexuals a fundamental right to engage in sodomy, because "[p]roscriptions against that conduct have ancient roots."16 While earlier cases did create a right to privacy extending to child-rearing and education, family relationships, procreation, marriage, contraception, and abortion, "none of the rights announced in those cases bears any resemblance to the claimed constitutional right of homosexuals to engage in acts of sodomy that is asserted in this case."17 Because no fundamental right was involved, the Constitution required only some rational basis for the law, and the Court found sufficient "the presumed belief of a majority of the electorate in Georgia that homosexual sodomy is immoral and unacceptable."18

Justices Blackmun and Stevens each wrote dissenting opinions, both joined by Justices Brennan and Marshall. ${ }^{19}$ Both suggested that Loving demonstrated the unsoundness of the majority's analysis. Blackmun argued that Loving revealed the fallacy of the argument "that either the length of time a majority has held its convictions or the passions with which it defends them can withdraw legislation from this Court's scrutiny." 20 In a footnote, he added that "[t]he parallel between Loving and this case is almost uncanny," and observed that both of the challenged laws had religious justifications, that both were similar to laws on the books when the Fourteenth Amendment was ratified, and that in both cases many states still had similar laws on the books at the time the case was decided." "Yet the Court held, not only that the invidious racism of Virginia's law violated the Equal Protection Clause . . . but also that the law deprived the Lovings of due process by denying them the 'freedom of

\footnotetext{
16. 478 U.S. at 192.

17. Id. at $190-91$ (citing cases).

18. Id. at 196. Chief Justice Burger and Justice Powell filed concurring opinions. Burger noted that condemnation of homosexual practices "is firmly rooted in Judaeo-Christian moral and ethical standards." Id. Powell wrote that "a prison sentence for such conduct-certainly a sentence of long duration-would create a serious Eighth Amendment issue" of excessive punishment, id. at 197, but concluded that this issue was not before the court because Hardwick "has not been tried, much less convicted and sentenced." Id. at 198. But see Carter v. State, 255 Ark. 225, 232-33, 500 S.W.2d 368, 373 (1973), cert. denied, 416 U.S. 905 (1974) (rejecting claim that eight-year sentences for single act of consensual homosexual sex constituted cruel and unusual punishment).

19. Blackmun argued that "this case is about "the most comprehensive of rights and the right most valued by civilized men,' namely, 'the right to be let alone.' " 478 U.S. at 199 (Blackmun, J., dissenting) (quoting Olmstead v. United States, 277 U.S. 438, 478 (1928) (Brandeis, J., dissenting)). Stevens argued that since the statute by its terms applied to all sodomy, heterosexual or homosexual, even if the partners were married, it ran directly afoul of the right to marital privacy announced in Griswold v. Connecticut, 381 U.S. 479 (1965). Nor had Georgia articulated any "neutral and legitimate interest" justifying selective enforcement. 478 U.S. at 219 (Stevens, J., dissenting).
}

20. Id. at 210 (Blackmun, J., dissenting).

21. Id. at 210 n.5. 
choice to marry' that had 'long been recognized as one of the vital personal rights essential to the orderly pursuit of happiness by free men." "222 Stevens, too, observed that "neither history nor tradition could save a law prohibiting miscegenation from constitutional attack." ${ }^{23}$ In a footnote, he added that "[i]nterestingly, miscegenation was once treated as a crime similar to sodomy." 24

This Note argues that the miscegenation analogy is an even more powerful tool for constitutional analysis than these opinions recognize: The Court's miscegenation precedents, together with its sex discrimination jurisprudence, are sufficient to invalidate the sodomy laws.

\section{Sodomy Law as Sex-Based Classification}

\section{A. The Threshold Question}

The threshold question is whether statutes that prohibit intercourse between persons of the same sex impose a sex-based classification. If they do, then the statute's validity is cast into doubt. Gender classifications trigger heightened scrutiny-not, to be sure, as intensive as that applied to racial classifications, but nonetheless exacting. ${ }^{25}$

It appears that only one court has considered this constitutional question, ${ }^{28}$ and it has answered it in the negative. In State $v$. Walsh, ${ }^{27}$ the Supreme Court of Missouri reversed a lower court's declaration that a statute prohibiting "deviate sexual intercourse with another person of the same sex" 28 deprived the defendant of equal protection because " the statute would not be applicable to the defendant if he were a female." "29

The State concedes that the statute prohibits men from doing what women may do, namely, engage in sexual activity with men. However, the State argues that it likewise prohibits women from doing something which men can do: engage in sexual activity with women. We believe it applies equally to men and women because it prohibits

22. Id. at $211 \mathrm{n} .5$ (quoting Loving, 388 U.S. at 12).

23. Id. at 216 (Stevens, J., dissenting).

24. Id. at 216 n.9. The analogy with Loving was also suggested by the Ninth Circuit in Watkins v. United States Army, 847 F.2d 1329, 1351-52, reh'g en banc ordered, 847 F.2d 1362 (9th Cir. 1988).

25. The Court has held that "the party seeking to uphold a statute that classifies individuals on the basis of their gender must carry the burden of showing an 'exceedingly persuasive justification' for the classification." Mississippi Univ. for Women v. Hogan, 458 U.S. 718, 724 (1982) (quoting Kirchberg v. Feenstra, 450 U.S. 455, 461 (1981), and Personnel Adm'r v. Feeney, 442 U.S. 256, 273 (1979)); $c f$. infra note 55 and accompanying text.

26. The sex discrimination issue was raised, but not reached, in Baker v. Wade, $553 \mathrm{~F}$. Supp. 1121,1144 (N.D. Tex. 1982), rev'd on other grounds, 769 F.2d 289 (5th Cir. 1985), cert. denied, 478 U.S. 1022 (1986).

27. 713 S.W.2d 508 (Mo. 1986) (en banc).

28. Mo. ANN. Stat. $\$ 566.090 .1(3)$ (Vernon 1979).

29. 713 S.W.2d at 509. 
both classes from engaging in sexual activity with members of their own sex. Thus, there is no denial of equal protection on that basis. ${ }^{30}$

The Missouri court's argument is essentially that of an 1883 Supreme Gourt decision, Pace v. Alabama, ${ }^{31}$ in which the Court considered for the first time the constitutionality of the miscegenation laws. The statute in question in Pace prescribed penalties for interracial sex more severe than those imposed for adultery or fornication between persons of the same race. The Court unanimously rejected the equal protection challenge to the statute, and denied that the two sections discriminated on the basis of race:

[The section prohibiting interracial sex] prescribes a punishment for an offence which can only be committed where the two sexes are of different races. There is in neither section any discrimination against either race .... Whatever discrimination is made in the punishment prescribed in the two sections is directed against the offence designated and not against the person of any particular color or race. The punishment of each offending person, whether white or black, is the same. ${ }^{32}$

The structure of Walsh's reasoning is identical to that of Pace: The Missouri statute prescribes a punishment for an offense which can only be committed where the two participants are of the same sex, and it is directed against the offense designated and not against the person of any particular sex.

But Pace is no longer good law. It was repudiated by the Supreme Court in the next miscegenation case it considered, McLaughlin v. Florida. ${ }^{33}$ In the wake of Brown v. Board of Education, ${ }^{34}$ the McLaughlin Court, again unanimously, invalidated a criminal statute prohibiting an unmarried interracial couple from habitually living in and occupying the same room at night. "It is readily apparent," wrote Justice White for the Court, that the statute "treats the interracial couple made up of a white person and a Negro differently than it does any other couple."35 In response to the state's reliance on Pace, White declared that "Pace represents a limited view of the Equal Protection Clause which has not with-

30. Id. at 510. The same argument has been used to reject Title VII claims that discrimination against gays is sex discrimination. See DeSantis v. Pacific Tel. \& Tel. Co., 608 F.2d 327, 331 (9th Cir. 1979); Smith v. Liberty Mut. Ins. Co., 395 F. Supp. 1098, 1099 n.2 (N.D. Ga. 1975), affd, 569 F.2d 325, 327 (5th Cir. 1978); see also Valdes v. Lumbermen's Mut. Casualty Co., 507 F. Supp. 10 (S.D. Fla. 1980) (discrimination against lesbians may constitute actionable "sex-plus" discrimination, but employer can rebut charge by showing that it discriminates equally against gay men).

31. 106 U.S. 583 (1883).

32. Id. at 585 .

33. 379 U.S. 184 (1964).

34. 347 U.S. 483 (1954).

35. 379 U.S. at 188. 
stood analysis in the subsequent decisions of this Court." ${ }^{\text {"36 }}$ Racial classifications, he concluded, can only be sustained by a compelling state interest. Since the state had failed to establish that the law served "some overriding statutory purpose requiring the proscription of the specified conduct when engaged in by a white person and a Negro, but not otherwise," ${ }^{37}$ the statute fell as "an invidious discrimination forbidden by the Equal Protection Clause." 38

McLaughlin stands for the proposition (which should be obvious even without judicial support) that if a statute defines prohibited conduct by reference to a characteristic, then the statute is not neutral with respect to that characteristic. Thus, the appropriate rejoinder to arguments like that of the Missouri court is that if the defendant had been a woman, he could not have been prosecuted for engaging in sexual conduct with a man. ${ }^{39}$ Indeed, the sexes of the participants would appear to be one of the material elements of the crime that the prosecution must prove. ${ }^{40}$ To paraphrase McLaughlin, it is readily apparent that the statute treats the samesex couple differently than it does any other couple. "Such a practice does not pass the simple test of whether the evidence shows 'treatment of a person in a manner which but for the person's sex would be different." "41

\section{B. Facially Gender-Neutral Statutes}

Of the twenty-five states that still prohibit consensual sodomy, only seven have statutes which apply only to homosexual behavior. ${ }^{42}$ The statutes of eighteen states and the District of Columbia, however, prohibit oral or anal sex regardless of whether the sexes of the participants are the same. ${ }^{43}$ It may thus appear that these, at least, do not classify on the basis

36. Id.

37. Id. at 192 .

38. Id. at 192-93; cf. Shelley v. Kraemer, 334 U.S. 1, 22 (1948) (rejecting Pace-like defense of racially restrictive covenants, because "[e]qual protection is not achieved through indiscriminate imposition of inequalities.").

39. Cf. Gutwein v. Easton Publishing Co., 272 Md. 563, 566, 325 A.2d 740, 742 (1974) (antidiscrimination case rejecting defense that firing of white employee because he was engaged to black woman "involved not his own race, but rather his fiancee's"), cert. denied, 420 U.S. 991 (1975).

40. Cf. Jones v. Commonwealth, $80 \mathrm{Va}$. 538, 542 (1885):

To be a negro is not a crime; to marry a white woman is not a crime; but to be a negro, and being a negro, to marry a white woman is a felony; therefore, it is essential to the crime that the accused shall be a negro-unless he is a negro he is guilty of no offence.

41. City of Los Angeles Dept. of Water \& Power v. Manhart, 435 U.S. 702, 711 (1978) (Title VII prohibits assessment of larger pension fund contributions from female employees, even though as a class women live longer than men) (quoting Developments in the Law-Employment Discrimination and Title VII of the Civil Rights Act of 1964, 84 HARv. L. REv. 1109, 1170 (1971)).

42. ARk. Stat. ANN. $\$ 41-1813$ (1977); Kan. Stat. ANN. § 21-3505 (Supp. 1987); Ky. Rev. Stat. AnN. § 510.100 (Michie/Bobbs-Merrill 1985); Mo. AnN. STat. § 566.090.1(3) (Vemon 1979); Mont. Code ANN. $\S \S 45-2-101(20), 45-5-505$ (1985); Nev. Rev. Stat. ANN. $\S 201.190$ (Michie 1986); Tex. Penal Code AnN. § 21.06 (Vernon 1968).

43. Ala. Code $\S \S 13 A-6-60(2), 13 A-6-65(a)(3)$ (1982); ARIz. Rev. Star. ANN. §§ 13-1411, 131412 (Supp. 1987) (oral sex excluded, State v. Potts, 75 Ariz. 211, 213, 254 P.2d 1023, 1024 (1953)); D.C. Code ANN. § 22-3502 (1981); Fla. Stat. ANN. § 800.02 (Harrison 1976); Ga. Code AnN. § 
of sex. But the usefulness of the miscegenation analogy has not yet been exhausted. ${ }^{44}$

It seems to be settled law, following the right to marital privacy announced in Griswold v. Connecticut, ${ }^{45}$ that such statutes are unconstitutional as applied to married couples. ${ }^{48}$ Thus, men may commit sodomitic sex acts with women if they marry them. But because every state forbids gay couples to marry, they cannot escape the prohibition of sodomy. The only basis of this discrimination is sex.

In the Jim Grow South, interracial marriages were not invariably criminalized as such. In some states, such marriages were simply void, in the same way that a gay marriage is today. There were nonetheless criminal prosecutions for fornication. ${ }^{17}$ The fornication statutes were raceneutral, but the guilt or innocence of the defendants was dependent upon their race. Similarly, so long as states forbid gays from marrying and thus from bringing themselves under the protection of Griswold, the use of facially gender-neutral sodomy laws to make criminals of them discriminates invidiously on the basis of sex. ${ }^{48}$

These statutes may also be sex-based because they manifest an intention to injure gays. The test for evaluating facially gender-neutral statutes that allegedly discriminate on the basis of sex was set forth by the Court in Personnel Administrator v. Feeney." Although adverse "impact pro-

16-6-2 (1984); IdAHo CODE $\S 18-6605$ (1987); La. Rev. STAT. ANN. $\$ 14: 89$ (West 1986); MD. ANN. Code art. 27, $\S \S 553,554$ (1987); Mass. Gen. Laws ANN. ch. 272, § 34 (West 1970); Mich. Comp. Laws $\S \S 750.158,750.338,750.338 a, 750.338 b$ (1981); MinN. STat. $\S 609.293$ (1987); MIss. CoDE ANN. \& 97-29-59 (1973) (excluding cunnilingus, because "[plenetration of the body is essential to the offense," State v. Hill, 179 Miss. 732, 735, 176 So. 719, 720 (1937)); N.C. GEN. STAT. \$14-177 (1981) (cunnilingus illegal only if tongue penetrates vagina, State v. Joyner, 295 N.C. 55, 66, 243 S.E.2d 367, 374 (1978)); OKLA. STaT. tit. 21, $\$ \$ 886,887$ (1983) (tongue must penetrate, Hicks v. State, 713 P.2d 18, 20 (1986)); R.I. GEN. LAws $\$ 11-10-1$ (1981); S.C. Code ANN. § 16-15-120 (Law. Co-op. 1985); TENN. Code ANN. § 39-2-612 (1982); UtAH Code ANN. § 76-5-403 (Supp. 1987); VA. CoDE ANN. § 18.2-361 (1982) (tongue must penetrate, Ryan v. Commonwealth, 219 Va. 439 , 444, 247 S.E.2d 698,702 (1978)).

44. The argument of the following two paragraphs was suggested by Prof. Akhil Amar of Yale Law School.

45. 381 U.S. 479 (1965).

46. See Bowers, 478 U.S. at 216-18 (Stevens, J., dissenting); Lovisi v. Slayton, 539 F.2d 349, 351 (4th Cir. 1976) (en banc), cert. denied, 429 U.S. 977 (1976); Cotner v. Henry, 394 F.2d 873, 875 (7th Cir. 1968), cert. denied, 393 U.S. 847 (1968). Since Griswold, there has been no authority to the contrary.

47. See, e.g., Hoover v. State, 59 Ala. 57 (1877); State v. Hooper, 27 N.C. (5 Ired.) 201 (1844); State v. Fore, 23 N.C. (1 Ired.) 378 (1841); Bartelle v. United States, 2 Okla. Crim. 84, 100 P. 45 (1908). One court explained that its state originally penalized only the clergyman who performed the marriage, but that this did not prevent the parties from continuing to live as man and wife. The newer law voiding the marriage, and thus subjecting them to prosecution for fornication, was a more effective remedy for this "evil." State v. Melton, 44 N.C. (Busb.) 49, 51 (1852).

48. Cf. Personnel Adm'r v. Feeney, 442 U.S. 256, 275 (1979) ("If the impact of this statute could not be plausibly explained on a neutral ground, impact itself would signal that the real classification made by the law was in fact not neutral."). But cf. Geduldig v. Aiello, 417 U.S. 484 (1974) (discrimination against pregnant persons is not sex-based discrimination).

49. 442 U.S. 265 (1979). In order to be facially neutral, and thus to be appropriately scrutinized under the Feeney test, a statute must, of course, be neutrally applied. Id. at 272 (citing Yick Wo v. Hopkins, 118 U.S. 356 (1886)). If a facially neutral statute is enforced only against gays, it is 
vides an 'important starting point' . . purposeful discrimination is 'the condition that offends the Constitution." " its intent-based test for invidious discrimination from Village of Arlington Heights v. Metropolitan Housing Development Corp., a racial discrimination case." Arlington Heights held that a plaintiff is not required "to prove that the challenged action rested solely on racially discriminatory purposes . . . [R]acial discrimination is not just another competing consideration. When there is a proof that a discriminatory purpose has been a motivating factor in the decision, this judicial deference is no longer justified."

In each of the states where sodomy statutes remain on the books, animus against lesbians and gays has been a major, if not the sole, reason for the decision to retain them. It has surely been "a motivating factor." For example, while Georgia's statute is facially gender-neutral, the state defended it before the Supreme Court "both in its brief and at oral argument . . . solely on the grounds that it prohibits homosexual activity." These statutes are thus constitutionally equivalent to those which are expressly directed solely against gays. ${ }^{54}$

equivalent to a facially anti-gay statute, regardless of the legislators' intent. Cf. Bowers, 478 U.S. at 203 n.2 (Blackmun, J., dissenting).

50. 442 U.S. at 274 (quoting Village of Arlington Heights v. Metropolitan Hous. Dev. Corp., 429 U.S. 252, 266 (1977), and Swann v. Charlotte-Mecklenburg Bd. of Educ., 402 U.S. 1, 16 (1971)).

51. 429 U.S. 252 (1977). While Arlington Heights was a racial discrimination case, the Feeney Court declared that its "principles apply with equal force to a case involving alleged gender discrimination." 442 U.S. at 274. 277.

52. Arlington Heights, 429 U.S. at 265-66 (emphasis supplied); accord Feeney, 442 U.S. at 276,

53. Bowers, 478 U.S. at 201 (Blackmun, J., dissenting). It did so because the statute would concededly have been unconstitutional if it were construed to apply, as by its terms it did, to sodomitic acts committed by married couples. Tr. of Oral Argument at 8, Bowers. Similarly, the desire to repress homosexuality was the major "motivating factor" in the retention of the District of Columbia's sodomy statute, which is facially gender-neutral. See D.C. CoDE ANN. § 22-3502 (1981). In 1981, the D.C. City Council, by a vote of 13 to 0 , decided to repeal this statute. The decision was overturned by a vote of the House of Representatives, which under the Home Rule Act of 1973 retains the right to invalidate any act of the D.C. government. In the debate preceding the House vote, homosexuality was a major theme, while heterosexual sodomy was barely discussed. "A vote to table or postpone is a vote to legalize sodomous homosexual liaisons," Representative Philip Crane, the sponsor of the resolution disapproving the Council's action, declared. 127 CoNG. Rec. 22,749 (1981). According to Representative Larry McDonald, if the House let the Council's vote stand, "then we are clearly saying that God owes Sodom and Gomorrah an apology." Id. at 22,752. See also id. at 22,750 (remarks of Rep. Daniel Crane); id. at 22,771 (remarks of Rep. Dan Marriott); id. at 22,766 (remarks of Rep. Parren Mitchell) (deploring debate's exclusive focus on homosexuality).

54. Even the traditional prohibition of sodomy, which did not distinguish homosexual from heterosexual acts, may have manifested an intent to maintain sexual boundaries. The prohibition's application to heterosexual sex, by forbidding any person, male or female, from engaging in any sexual act which it is anatomically possible for a person of the opposite sex to perform, reinforces the ideology of "men being entirely distinct from women in use, in function, in posture and position, in role, in 'nature." " A. DWORKIN, INTERCourse 160 (1987); see also id. at 156-57. 


\section{Sodomy Law as Sex Discrimination}

It has thus far been established that the sodomy laws establish sexbased classifications, and therefore, in order to withstand constitutional challenge, "must serve important governmental objectives and must be substantially related to the achievement of those objectives." verbal formula, without more, seems so vague as to be practically meaningless. ${ }^{56}$ In this Section, Subsection A will show that in application the Court has given this test at least this much meaning: Sex-based classifications are unconstitutional if their purpose is to impose traditional sex roles. Subsection B will then argue that this is precisely the purpose that the sodomy laws serve, and that such laws therefore violate the Fourteenth Amendment. Finally, Subsection $\mathrm{C}$ will argue that if this impermissible purpose is excluded from consideration, these statutes seem purposeless indeed and thus cannot withstand even minimal scrutiny.

\section{A. The Constitutional Test for Sex-Based Classifications}

McLaughlin simply ignored the purpose of the statute it was scrutinizing. One writer suggests that the Court did this because it was a "simpler and easier" way to invalidate the statute: "Declaring that all racial discrimination was suspect eliminated any need to show that antimiscegenation laws were premised on racial inequality . . ." ${ }^{\mathbf{5 z}}$ Indeed, McLaughlin does not seem to have relied on strict scrutiny as such, since a statute that has no purpose at all cannot even survive the lenient "rational relationship" test. Similarly, it is possible for a court to simply hold that the sex-based classification imposed by a sodomy law is arbitrary and therefore unconstitutional. ${ }^{58}$ But this, like McLaughlin, fails to address the powerful moral convictions that the statute reflects. To be persuasive, an argument against the sodomy laws must show that such moral convictions are not a sufficient justification for the law. The miscegenation laws were not purposeless exercises of state power, and neither are the sodomy laws.

The McLaughlin Court, in invalidating a prohibition of interracial cohabitation, expressly refrained from reaching the question of the validity of the state's prohibition of interracial marriage. ${ }^{.9}$ When that issue was resolved three years later, in Loving $v$. Virginia, ${ }^{60}$ the Court finally discerned the purpose that underlay the miscegenation statutes. ${ }^{61}$ This time,

55. Craig v. Boren, 429 U.S. 190, 197 (1976).

56. See id. at 221 (Rehnquist, J., dissenting) (test is "so diaphanous and elastic as to invite subjective judicial preferences or prejudices relating to particular types of legislation, masquerading as judgments whether such legislation is directed at 'important' objectives or, whether the relationship to those objectives is 'substantial' enough.").

57. J. BAER, supra note 13 , at 118 .

58. See infra notes $96-104$ and accompanying text.

59. 379 U.S. at $195,196$.

60. 388 U.S. 1 (1967).

61. One earlier Supreme Court decision did recognize the actual significance of the miscegenation 
the state abandoned Pace and simply appealed for judicial restraint: "[I]t is the exclusive province of the Legislature of each State to make the determination for its citizens as to the desirability of a policy of permitting or preventing such alliances-a province which the judiciary may not constitutionally invade." ${ }^{\prime 22}$ Justice Stewart responded, as he had in McLaughlin, that "it is simply not possible for a state law to be valid under our Constitution which makes the criminality of an act depend upon the race of the actor.' "'ss But no other Justice joined Stewart's concurrence. Rather, the majority in Loving focused directly on the purpose of the statute's racial classifications.

Chief Justice Warren, writing for the Court, observed that the Supreme Court of Appeals of Virginia had held "that the State's legitimate purposes were 'to preserve the racial integrity of its citizens,' and to prevent 'the corruption of blood,' 'a mongrel breed of citizens,' and 'the obliteration of racial pride,' obviously an endorsement of the doctrine of White Supremacy." "n this evidence, he concluded that "the racial classifications must stand on their own justification, as measures designed to maintain White Supremacy," lates the central meaning of the Equal Protection Clause."66

As with race, the Court has not confined its pronouncements on gender to denunciations of irrationality, but has also inquired into the purposes served by sex-based classifications. It has explained that the reason for heightened scrutiny is that "[c]lassifications based upon gender, not unlike those based upon race, have traditionally been the touchstone for pervasive and often subtle discrimination." ${ }^{.67}$ It is because sex-based classifications have been instruments of the subordination of women that they arouse judicial suspicion; otherwise, they would not need any greater justification than a rational relationship to a permissible state purpose. ${ }^{68}$

In determining whether a statute serves important governmental objectives, the Court has held that "[c]are must be taken in ascertaining whether the statutory objective itself reflects archaic and stereotypic notions." "69 These "archaic and stereotypic notions" are often identified as being merely inaccurate empirical generalizations. ${ }^{70}$ But the impermissible

statutes as a "stigma, of the deepest degradation . . . fixed upon the whole [black] race." Dred Scott v. Sandford, 60 U.S. (19 How.) 393, 409 (1857).

62. Brief for Appellee at 7-8, Loving v. Virginia, 388 U.S. 1 (1967) (No. 395).

63. 388 U.S. at 13 (Stewart, J., concurring) (quoting McLaughlin, 379 U.S. at 198 (Stewart, J., concurring)).

64. Id. at 7 (quoting Naim v. Naim, 197 Va. 80, 90, 87 S.E.2d 749, 756 (1955)).

65. Id. at 11 .

66. Id. at 12 .

67. Personnel Adm'r v. Feeney, 442 U.S. 256, 273 (1979).

68. On the rational relationship test, see City of Cleburne v. Cleburne Living Center, Inc., 473 U.S. 432, 440 (1985), and citations therein.

69. Mississippi Univ. for Women v. Hogan, 458 U.S. 718, 725 (1982).

70. See, e.g., id. at 725-26; Frontiero v. Richardson, 411 U.S. 677, 686 (1973) (plurality opinion). 
notions also include the normative notion that women should not act in ways that are unseemly for their sex. The Court has consistently struck down statutes the purpose of which was the imposition of traditional gender roles. ${ }^{21}$

The rationale for these holdings is most clearly evident in Stanton $v$. Stanton, ${ }^{72}$ in which the Court invalidated a statute requiring parents to support their sons until age twenty-one, but their daughters only until age eighteen. The state argued in defense of the law "that it is the man's primary responsibility to provide a home and that it is salutary for him to have education and training before he assumes that responsibility." ${ }^{.73}$ The Court acknowledged that this "may be true," ${ }^{\prime 4}$ but it remained unpersuaded.

No longer is the female destined solely for the home and the rearing of the family, and only the male for the marketplace and the world of ideas .... To distinguish between the two on educational grounds is to be self-serving: if the female is not to be supported so long as the male, she hardly can be expected to attend school as long as he does, and bringing her education to an end earlier coincides with the role-typing society has long imposed. ${ }^{75}$

This holding is inexplicable in terms of the statute's rationality. If the state's purpose was to maintain a pattern of sex relationships in which "it is the man's primary responsibility to provide a home," so that women

71. Mississippi Univ. for Women held unconstitutional a state nursing school's policy of denying admission to males. The Court observed that the exclusion of males "tends to perpetuate the stereotyped view of nursing as an exclusively woman's job." 458 U.S. at 729 . This policy "lends credibility to the old view that women, not men, should become nurses, and makes the assumption that nursing is a field for women a self-fulfilling prophecy." Id. at 730. The Court also noted evidence indicating that this putatively preferential treatment had harmed rather than helped women: "Officials of the American Nurses Association have suggested that excluding men from the field has depressed nurses' wages." Id. at 729 n.15.

In Orr v. Orr, 440 U.S. 268 (1979), the Court invalidated a law permitting alimony payments to be imposed only on husbands upon divorce. The Court noted that its "prior cases settle" that the Constitution does not permit laws "announcing the State's preference for an allocation of family responsibilities under which the wife plays a dependent role, and . . . seeking for their objective the reinforcement of that model among the State's citizens." Id. at 279. "Legislative classifications which distribute benefits and burdens on the basis of gender carry the inherent risk of reinforcing stereotypes about the 'proper place' of women," and therefore "must be carefully tailored" to avoid carrying "the baggage of sexual stereotypes." Id. at 283.

In Weinberger v. Wiesenfeld, 420 U.S. 636 (1975), the Court invalidated a Social Security provision that granted lower survivors' benefits to widowers and their children than to widows and their children. The traditional sexual division of labor, the Court held, could not justify "the denigration of the efforts of women who do work and whose earnings contribute significantly to their families' support." Id. at 645. "The fact that a man is working while there is a wife at home does not mean that he would, or should be required to, continue to work if his wife dies." Id. at 651-52 (emphasis added).

72. 421 U.S. 7 (1975).

73. Id. at 14; see Stanton v. Stanton, 30 Utah 2d 315, 318-19, 517 P.2d 1010, 1012 (1974); Brief for Appellee at 18, Stanton v. Stanton, 421 U.S. 7 (1975) (No. 73-1461).

74. 421 U.S. at 14.

75. Id. at $14-15$. 
would remain economically dependent on men, then this statute would appear to be quite narrowly tailored to that goal. The fact that the practice promoted in the statute "coincides with the role-typing society has long imposed" should be a strength, not a weakness, under the rational relationship test. The problem with the statute is rather that it forces women to follow traditional sex roles and thus keeps them locked in a subordinate social and economic position. ${ }^{76}$ For this reason, the imposition of role-typing can never constitute an "important governmental objective[]." It is, indeed, not even a permissible one. ${ }^{78}$ The Court has not announced any exception for cases in which the desire for role-typing is so powerful that it takes the form of deep moral conviction. To do so would vitiate the principle altogether, since all sexual role-typing has traditionally been thought to possess such moral force. ${ }^{79}$

76. Cf. Plyler v. Doe, 457 U.S. 202, 213 (1982) ("The Equal Protection Clause was intended to work nothing less than the abolition of all caste-based and invidious class-based legislation.").

77. Craig v. Boren, 429 U.S. 190, 197 (1976).

78. Those decisions in which the Court has upheld traditional gender classifications are not to the contrary, because in those cases the classifications were found to comport with, rather than to impose, differences between the sexes. Thus, for example, in Michael M. v. Superior Court, 450 U.S. 464 (1981), the Court upheld a statutory rape law which punished the male, but not the female, participant in intercourse when the female was under 18 and not the male's wife. "Because virtually all of the significant harmful and inescapably identifiable consequences of teenage pregnancy fall on the young female," Justice Rehnquist's plurality opinion explained, "a legislature acts well within its authority when it elects to punish only the participant who, by nature, suffers few of the consequences of his conduct." Id. at 473 . Thus, the statute did not rest merely on "the baggage of sexual stereotypes." "Id. at 476 (quoting $0 \mathrm{rr}, 440$ U.S. at 283). Rehnquist nowhere suggests that such stereotyping is permissible; instead he relies on the fact that "this Court has consistently upheld statutes where the gender classification is not invidious, but rather realistically reflects the fact that the sexes are not similarly situated in certain circumstances." Id. at 469.

This distinction has been criticized for insulating longstanding patterns of domination from scrutiny. Some differences between the sexes are quite real, but arguably exist only because they have been imposed by society for a long time. See C. MacKinnon, Sexual. Harassment of Working Women 120-21 (1979); Law, Rethinking Sex and the Constitution, 132 U. PA. L. Rev. 955 (1984). But whatever the deficiencies of the Court's approach, this Note does not rely on a radical revision of the Court's sex discrimination doctrine. It argues only that the existing doctrine should be applied consistently. But of. Law, Homosexuality and the Social Meaning of Gender, 1988 Wis. L. REv. 187, 229 [hereinafter Law, Homosexuality] (arguing that Court has failed to hold squarely that enforcing traditional visions of family and sexuality is not legitimate state interest, and that this makes it difficult for gays to argue that these traditional concepts are insufficient to justify denial of their liberty).

79. For example, in Bradwell v. State, 83 U.S. (16 Wall.) 130, 141 (1872), in which the Court upheld a law that forbade women to practice law, Justice Bradley, concurring, explained the powerful moral beliefs on which his decision rested: "The paramount destiny and mission of woman are to fulfil the noble and benign offices of wife and mother. This is the law of the Creator." Compare the following statement of why lesbianism is forbidden: "The Creator has endowed the bodies of women with the noble mission of motherhood and the bringing of human life into the world. Any woman who violates this great trust by participating in homosexuality not only degrades herself socially but also destroys the purpose for which God created her." This statement was part of a 1952 indoctrination lecture on homosexuality given by Navy chaplains to WAVE recruits, reprinted in Bérubé \& D'Emilio, The Military and Lesbians during the McCarthy Years, 9 Signs 759, 769 (1984). The miscegenation laws, of course, rested on equally powerful moral convictions:

The purity of public morals, the moral and physical development of both races, and the highest advancement of our cherished southern civilization, under which two distinct races are to work out and accomplish the destiny to which the Almighty has assigned them on this continent-all require that they should be kept distinct and separate, and that connections and alliances so unnatural that God and nature seem to forbid them, should be prohibited by positive law, and be subject to no evasion. 


\section{B. The Function of the Sodomy Laws}

Do statutes that outlaw homosexual sex impose traditional sex roles? One possible answer is that of McLaughlin: The crime is by definition one of engaging in activity inappropriate to one's sex. But these statutes' inconsistency with the Constitution's command of equality is deeper. Like the miscegenation statutes, the sodomy statutes reflect and reinforce the morality of a hierarchy based on birth. Just as the prohibition of miscegenation preserved the polarities of race on which white supremacy rested, ${ }^{80}$ so the prohibition of sodomy preserves the polarities of gender on which rests the subordination of women. ${ }^{81}$

Begin by considering the familiar conservative defense of the sodomy laws, which is that the traditional prohibition of homosexual acts is necessary in order to protect the family. ${ }^{82}$ It is, at first blush, a curious notion. Most heterosexual family members do not appear to be so eager to become homosexual that only the fear of externally imposed sanctions prevents them from doing so. Many homosexual relationships are, except for the sex of the participants and the legal status of the union, indistinguishable from heterosexual marriages, ${ }^{83}$ and adoption and new reproductive technologies have made it possible for increasing numbers of gay couples to raise children. ${ }^{84}$ Moreover, there have been cultures in which homosexuality has been openly tolerated, ${ }^{85}$ and in them families do not appear to

Kinney v. Commonwealth, 71 Va. (30 Gratt.) 858, 869, 32 Am. Rep. 690, 699 (1878).

80. See Davis, Intermarriage in Caste Societies, 43 AM. ANTHRopologist (n.s.) 376, 389 (1941) (since marriage between races would create mixed-race heirs, "either intermarriage must be strictly forbidden or racial caste abandoned."); Saks, Reproducing Miscegenation Law, 8 RARIraN, Fall, 1988 at 39 (anxiety about boundaries pervaded legal discourse on miscegenation).

81. This thesis is also developed in Law, Homosexuality, supra note 78.

82. This theme appears repeatedly in the briefs in Bowers, both by the state and by the amici supporting its position. Thus the state argued that "homosexual sodomy is the anathema of the basic units of our society - marriage and the family. To decriminalize or artificially withdraw the public's expression of its disdain for this conduct does not uplift sodomy, but rather demotes these sacred institutions to merely other alternative lifestyles." Brief for Petitioner at 37-38, Bowers v. Hardwick, 478 U.S. 186 (1986) (No. 85-140). Similar arguments appear in Brief of Amicus Catholic League for Religious and Civil Rights at 1, Brief of Amicus Concerned Women for America Education and Legal Defense Foundation at 2, and Brief of Amicus The Rutherford Institute at 26.

83. A study of San Francisco Bay area gays found that $29 \%$ of the men, and almost three-fourths of the women, were currently involved in a stable relationship. A. BELL \& M. WEINBERG, Homosexualities: A Study of Diversity Among Men and Women 91, 97 (1978). Many of these couples foster the same intimacy, caring, and enduring commitment that are valued in the most successful traditional marriages. See Peplau, Research on Homosexual Couples: An Overview, $8 \mathrm{~J}$. HomoseXuality 3 (1982), and citations therein.

84. See generally C. Pies, Considering Parenthood: A Workbook for Lesbians (1985). Indeed, gays have shown enough interest in nurturing children that measures have been proposed to forbid them from doing so. See Opinion of the Justices, 129 N.H. 290, 530 A.2d 21 (1987) (proposed act's exclusion of gays from foster care and adoption is constitutional, although their exclusion as operators of child care agencies is not).

85. See, e.g., J. Boswell, Christianity, Social Tolerance and Homosexualtty: Gay People in Western Europe from the Beginning of the Christian Era to the FourTEENTH CENTURy (1980) (homosexuality widely tolerated in Western Europe in first centuries of Christianity and during 11 th and 12 th centuries). 
have been less common or enduring than they are in contemporary America. How, then, can homosexuals be said to threaten the family?

Another datum helps to solve this mystery: Hostility to homosexuals is linked to other traditional, restrictive attitudes about sex roles. ${ }^{86}$ This suggests that Thomas Szasz is right: "[T]he homosexual does not threaten society by his actual behavior but rather by the symbolic significance of his acts." ${ }^{87}$ Homosexuality threatens not the family as such, but a certain traditional ideology of the family. That ideology is one in which men, but not women, belong in the public world of work and are not so much members as owners of their families ${ }^{88}$ while women, but not men, should rear children, manage homes, and obey their husbands. ${ }^{89}$ It has been under stress for a long time. Intolerance of homosexuality may have ancient roots, but its basis is no more historically invariant than that of racism or anti-semitism. Today that basis is anxiety about the boundaries of gender. ${ }^{90}$

Just as the central tenet of White Supremacy was the extreme differentiation of the races-so extreme that intercourse between them could be deemed "miscegenation," meaning literally the mixing of different species-so the central tenet of the subordination of women is the extreme differentiation of the sexes. The element of both differentiations that promotes hierarchy is the idea that certain anatomical features necessarily entail certain social roles: One's status in society is obviously and unproblematically determined by the color of one's skin or the shape of one's reproductive organs. Homosexuality threatens the hierarchy of the sexes because its existence suggests that even in that realm where a person's sex has been regarded as absolutely determinative, anatomy has less to do with destiny than one might have supposed.

Just as miscegenation was threatening because it called into question the distinctive and superior status of being white, homosexuality is threatening because it calls into question the distinctive and superior status of

86. Numerous studies by social psychologists support this conclusion. For example, one study found that "a major determinant of negative attitudes toward homosexuality is the need to keep males masculine and females feminine, that is, to avoid sex-role confusion . . . MacDonald \& Games, Some Characteristics of Those Who Hold Positive and Negative Attitudes Toward Homosexuals, $1 \mathrm{~J}$. Homosexuality 9, 19 (1974); see also Whitley, The Relationship of Sex-Role Orientation to Heterosexuals' Attitudes Toward Homosexuals, 17 SEx Roles 103 (1987), and citations therein. Even if such studies did not exist, a court might reasonably draw the same conclusion from ordinary experience. $C f$. infra note 96.

87. Szasz, Legal and Moral Aspects of Homosexuality, in Sexual INversion 124, 135 (J. Marmor ed. 1965).

88. For a defense of such arrangements, which does acknowledge that they have "disadvantages from the point of view of justice," see A. Bloom, The Closing of the American Mind 130 (1987).

89. A description of this ideology, which focuses on its role in the anti-abortion movement but is also useful in the present context, appears in K. LUKER, ABORTION AND THE POLITICs OF MOTHERHOOD 159-75 (1984).

90. Cf. Law, Homosexuality, supra note 78, at 197-206 (modern history of condemnation of homosexuality reveals its roots in patriarchal assumptions that deny equality of women). 
being male. '[M]en cannot simultaneously be used 'as women' and stay powerful because they are men." ${ }^{\text {"11 }}$ Lesbianism also challenges male privilege, but in a different way: It denies that female sexuality exists, or should exist, only for the sake of male gratification. The familiar insinuation that all radical feminists are lesbians supports Adrienne Rich's speculation that "men really fear . . . that women could be indifferent to them altogether, that men could be allowed sexual and emotional . . . access to women only on women's terms, otherwise being left on the periphery of the matrix." "פ2

Homosexuals are a threat to the family only if the survival of the family requires that men and women follow traditional sex roles. ${ }^{93}$ This view implies that the Court's consistent invalidation of laws that forcibly impose such roles has been a terrible mistake; that unless law continues to enforce rigid gender distinctions, people will no longer form stable units in which children can thrive. ${ }^{94}$ It is, essentially, an argument that equality is bad for society and inequality, good. Whatever the merits of this view, it is inconsistent with the Fourteenth Amendment. And if the amendment prohibits "keeping women in a stereotypic and predefined place" through such means as unequal insurance payments, child support requirements, or alimony, what can be said on behalf of laws that enforce role-typing by criminal penalties?

\section{The Arbitrariness of the Sodomy Laws}

As in McLaughlin, a court may prefer to say nothing about the troubling and controversial issue of the social meaning of the challenged statute, ${ }^{98}$ and instead may choose simply to let that meaning go unnoticed. As

91. A. Dworkin, Right-Wing Women 129 (1983); see A. Dworkin, supra note 54, ch. 8; Stoltenberg, You Can't Fight Homophobia and Protect the Pornographers at the Same Time, Changing MEN, Spring/Summer 1988, at 11.

92. Rich, Compulsory Heterosexuality and Lesbian Existence, 5 SIGNS 631, 643 (1980).

93. See Law, Homosexuality, supra note 78 , at 218-21.

94. While predictions cannot be disproven, it is noteworthy that similarly dire forecasts were made by opponents of female suffrage, see Letter from William E. Gladstone to Samuel Smith (Apr. 11,1892 ), reprinted in 2 Women, The Family, and Freedom: The Debate in Documents 222 (S. Bell \& K. Offen eds. 1983); of racial integration, see Borders v. Rippey, 184 F. Supp. 402, 404, 416 (N.D. Tex. 1960); Sass, Mixed Schools and Mixed Blood, 198 AtLantic Monthly, Nov. 1956, at 45; and even of the abolition of slavery, see G. Fitzhugh, Gannibals All! OR, Slaves Without MAsters (C. V. Woodward ed. 1960) (1st ed. 1857).

95. Personnel Adm'r v. Feeney, 442 U.S. 256, 279 (1979).

96. Racial discrimination cases provide numerous examples of judicial discomfort with the necessity, in adjudicating Fourteenth Amendment cases, of recognizing that statutes sometimes embody invidious social meanings. See, e.g., Plessy v. Ferguson, 163 U.S. 537, 551 (1896) (evading the issue by holding that if blacks believe that segregation law "stamps the colored race with a badge of inferiority," this is "not by reason of anything found in the act, but solely because the colored race chooses to put that construction upon it."); Brown v. Board of Educ., 347 U.S. 483, 494 n.11 (1954) (relying upon social science data to support holding that school segregation denotes inferiority of blacks); $R$. Kluger, Simple Justice: The History of Brown v. BoARD of Education and Black AMERICA'S STRUGGLE FOR EQUALITY 705-07, 712-13 (1976) (data cited in Brown were methodologically vulnerable and unnecessary to the Court's holding, which should have rebutted Plessy by com- 
noted earlier, this is a subterfuge and therefore is intellectually unsatisfying. But it produces no injustice if, as is true of both the miscegenation and the sodomy laws, that meaning would not be a permissible justification for the statute anyway. (It is, however, arguable that those who value the social roles traditionally associated with race and sex are at least entitled to an explanation of why they may not use the law to impose those roles on others, and that it is unjust for courts to intervene without providing such an explanation. ${ }^{87}$ ) With both miscegenation and sodomy laws, once the law's invidious purpose is excluded from consideration no articulable purpose remains, and the statute cannot withstand even minimal scrutiny.

A statute "providing dissimilar treatment for men and women who are ... similarly situated . . . violates the Equal Protection Clause." ${ }^{\text {"98 }}$ Of course, same-sex couples, like interracial couples, are differently situated in that their unions have traditionally been condemned as immoral and prosecuted as illegal. But we have seen that, because the relevant traditions contain inegalitarian premises that are inconsistent with the Fourteenth Amendment, these are not "distinguishing characteristics relevant to interests the State has the authority to implement.."99 And if the preservation of traditional sex roles is not an interest the state may invoke, then it is difficult to see how a state could meet its burden of proving that, for example, women who want to have sex with women are situated differently from men who want to have sex with women.

The Eleventh Circuit recognized this in Bowers when it declared that "For some, the sexual activity in question here serves the same purpose as the intimacy of marriage."100 Georgia's response, that this conclusion "has lowered the estate of marriage . . . to merely another alternative for sexual gratification,"101 implies that the satisfaction of sexual gratification is the only feature common to marriages and homosexual liaisons. This is demonstrably false. ${ }^{102}$ By conflating all homosexual intercourse with loveless sexual gratification, Georgia "relied upon the simplistic, outdated assumption that gender could be used as a "proxy for other, more germane bases of classification." "103

mon-sense reasoning). But see Strauder v. West Virginia, 100 U.S. 303, 308 (1880) (exclusion of blacks from juries "is practically a brand upon them, affixed by the law, an assertion of their inferiority, and a stimulant to that race prejudice which is an impediment to securing to individuals of the race that equal justice which the law aims to secure to all others.").

97. Cf. J.H. Wilkinson, From Brown to BAKKE. The Supreme Court and School InTEGRation, 1954-1978 38-39 (1979) (the Brown Court's failure to articulate persuasive reasons for its holding may have been politic, but forsook the ultimate basis of the Court's authority).

98. Reed v. Reed, 404 U.S. 71, 77 (1971).

99. City of Cleburne v. Cleburne Living Center, Inc., 473 U.S. 432, 441 (1985).

100. Hardwick v. Bowers, 760 F.2d 1202, 1212 (11th Cir. 1985), rev'd, 478 U.S. 186 (1986).

101. Brief for Petitioner, supra note 82, at 25.

102. See supra notes $83-84$ and accompanying text.

103. Mississippi Univ. for Women v. Hogan, 458 U.S. 718, 726 (1982) (quoting Craig v. Boren, 429 U.S. 190, 198 (1976)). To conflate homosexuality with promiscuity, and thus with the transmis- 
The arbitrariness of these statutes is well captured by Justice Traynor's statement in Perez $v$. Sharp, the first case in which a miscegenation law was held unconstitutional: "A member of any of these races [one might substitute "either of these sexes"] may find himself barred by law from marrying the person of his choice and that person to him may be irreplaceable. Human beings are bereft of worth and dignity by a doctrine that would make them as interchangeable as trains."104

\section{Prudence}

The thesis that laws directed against lesbians and gays discriminate unconstitutionally on the basis of gender has radical implications. If the Loving analogy is taken seriously, it follows that the equal protection clause forbids the denial of marriage licenses to gay couples, ${ }^{105}$ or the use of homosexuality as a basis for denying custody of a child. ${ }^{108}$ The prospect of the Court attempting to impose such results on a resistant society is, and should be, a daunting one. ${ }^{107}$

Miscegenation once presented a similar problem. ${ }^{108}$ Although the Court decided Brown in 1954, it avoided applying the logic of that holding to the miscegenation issue for the next thirteen years. In 1956, it dismissed a

sion of AIDS, see, e.g, Brief of Amicus David Robinson, Jr. at 7, Bowers v. Hardwick, 478 U.S. 186 (1986) (No. 85-140) ("Epidemiological concerns, evidenced by the AIDS tragedy, are inconsistent with a recognition of a constitutional right to engage in sodomy."); Pope John Paul II, Letter to Bishops on the Pastoral Care of Homosexual Persons (Oct. 1, 1985), 32 THE Pope SpeAks 62, 65 (1987) ("the practice of homosexuality may seriously threaten the lives and well-being of a large number of people"), is equally simplistic. See generally Brief of Amici American Psychological Association and American Public Health Association at 19-27, Bowers. A statute that sought to prevent disease by prohibiting all intercourse between gays, like one prohibiting all sexual intercourse whatsoever, would be "legislation not reasonably restricted to the evil with which it is said to deal." Butler v. Michigan, 352 U.S. 380, 383 (1957). "Surely, this is to burn the house to roast the pig." Id.

104. Perez v. Sharp, 32 Cal. 2d 711, 725-26, 198 P.2d 17, 25 (sub nom. Perez v. Lippold) (1948).

105. See Law, Homosexuality, supra note 78, at 230-32.

106. The final episode in the constitutional history of miscegenation came in Palmore v. Sidoti, 466 U.S. 429 (1984), in which the Court reversed a state court's decision to divest a white mother of the custody of her child because of her remarriage to a black man. The Court left undisturbed the lower court's finding that the child, if raised by the interracial couple, would suffer from "social stigmatization." Id. at 431 (emphasis deleted), see id. at 433-34. It held, however, that "[t]he Constitution cannot control such prejudices but neither can it tolerate them. Private biases may be outside the reach of the law, but the law cannot, directly or indirectly, give them effect." Id. at 433 . But cf. Jacobson v. Jacobson, 314 N.W.2d 78, 81 (N.D. 1981) (reversing custody award to mother, where living in same house with her and her lesbian lover would have caused children to "suffer from the slings and arrows of a disapproving society"); accord S v. S, 608 S.W.2d 64 (Ky. Ct. App. 1980), cert. denied, 451 U.S. 911 (1981).

107. Objections about the judiciary's arrogating to itself "authority to govern the country without express constitutional authority," Bowers, 478 U.S. at 195, are less troubling, unless one believes that the Court's miscegenation and sex discrimination decisions, too, were "judge-made constitutional law having little or no cognizable roots in the language or design of the Constitution." Id. at 194. Justice White, at least, does not appear to go so far. See supra notes 35-38 and accompanying text (discussing White's opinion in McLaughlin); Freedman, Sex Equality, Sex Differences, and the Supreme Court, 92 Yal. L.J. 913, 925 n.54 (1983) (documenting White's frequent support for Court's sex discrimination decisions). White also joined the unanimous Lotring decision.

108. On the political and psychological context within which Loving was decided, see R. SICKELS, Race, Marriage and the Law (1972). 
challenge to the same Virginia statute that it later struck down in Loving. ${ }^{109}$ Commentators harshly criticized this disposition of the case: Herbert Wechsler declared that the procedural grounds relied upon by the Court were "wholly without basis in the law,"110 and Gerald Gunther called the dismissal "indefensible."111

Alexander Bickel, however, thought that the Court's action was prudent. While a "judgment legitimating such statutes would have been unthinkable, given the principle of the School Segregation Cases," their invalidation would not have been "wise" at a time when the Court "was subject to scurrilous attack by men who predicted that integration of the schools would lead directly to 'mongrelization of the race' and that this was the result the Court had really willed . . .."112

It has been suggested that the Court's holding in Bowers was animated, and perhaps justified, by similar considerations of prudence. ${ }^{113}$ Prudence does not, however, adequately explain or justify what the Court did. Bickel believed that when constitutional principle clashes with expediency, the Court ought to "stay[] its hand" by "withholding constitutional judgment."114 By using its broad discretion to avoid deciding constitutional issues that it would be imprudent to adjudicate, the Court can "maintain itself in the tension between principle and expediency."115

If this is correct, then the Court's real mistake was to decide Bowers at all. ${ }^{116}$ Perhaps some lawlessness must be tolerated. Bickel believed that the Fourteenth Amendment's guarantee of equality "cannot in our society

109. Naim v. Naim, 197 Va. 80, 87 S.E.2d 749, vacated, 350 U.S. 891 (1955), on remand, 197 Va. 734, 90 S.E.2d 849, appeal dismissed, 350 U.S. 985 (1956). The Court also denied a petition for certiorari of a miscegenation conviction only a few months after Brown. Jackson v. Alabama, 348 U.S. 888 (1954). One member of the Court was reported to have remarked after leaving the Naim conference, "One bombshell at a time is enough." W. MurPhy, Elements of Judicial Strategy 193 (1964).

110. Wechsler, Toward Neutral Principles of Constitutional Law, 73 HARv. L. REv. 1, 34 (1959).

111. Gunther, The Subtle Vices of the "Passive Virtues"-A Comment on Principle and Expediency in Judicial Review, 64 Colum. L. Rev. 1, 12 (1964).

112. A. Bickel, The Least Dangerous Branch 174 (2d ed. 1986).

113. See, e.g., Galston, Public Morality and Religion in the Liberal State, 19 PS 807, 821 (1986):

The decision to submit this question [of the criminalization of sodomy] to the processes of majoritarian federalism rather than resolving it through judicial nationalism allows cultural differences among states to be reflected in their legal codes-and cultural changes to be transformed into legal changes at a sustainable pace. The state-level relaxation of antisodomy prohibitions has not for the most part generated the kind of divisive backlash that their nationally mandated abolition would almost surely produce.

114. A. BiCKEL, supra note 112 , at 70 .

115. Id. at 69 .

116. Bowers came to the Court upon a writ of certiorari. By denying certiorari, the Court would have permitted the Eleventh Circuit's invalidation of the Georgia statute to stand, but the constitutionality of sodomy laws would have remained unclear, since the lower courts would have been split on the issue. Compare Doe v. Commonwealth's Attorney, 403 F. Supp. 1199 (E.D. Va. 1975), affd mem., 425 U.S. 901 (1976) (rejecting constitutional challenge of state sodomy law) and Baker v. Wade, 769 F.2d 289 (5th Cir. 1985), cert. denied, 478 U.S. 1022 (1986) (same) with Hardwick v. Bowers, 760 F.2d 1202 (11th Cir. 1985) (invalidating statute), rev'd, 478 U.S. 186 (1986). 
constitute a hard and fast rule of action for universal immediate execution. This is nothing to be proud of. It is a disagreeable fact, and it cannot be wished away." 117 But there is a considerable distance between the toleration of lawlessness and its enthusiastic embrace. This is the measure of how far the Court went wrong in Bowers.

Because the Court did what it did, it is necessary to consider whether, as Judge Reinhardt of the Ninth Circuit recently suggested, the equal protection issue has already been resolved by Bowers. "When conduct that plays a central role in defining a group may be prohibited by the state," Reinhardt observes, "it cannot be asserted with any legitimacy that the group is specially protected by the Constitution." 118 Strictly speaking, this overreads Bowers: The Court restricted its opinion to the privacy question, and it expressly declined to reach issues which, if presented, might have produced an opposite result. ${ }^{119}$ Still, Reinhardt's analysis probably yields a sound prediction of how the Court would resolve the equal protection question, given the Bowers opinion's "anti-homosexual thrust . . . and the Court's willingness to condone anti-homosexual animus in the actions of the government." ${ }^{\prime 20}$

If so, the implications are ominous and far-reaching. If constitutional law is henceforth to enshrine the principle that laws cannot be unconstitutional so long as they "have ancient roots," tection jurisprudence of the past thirty-five years is called into doubt. If the touchstone of constitutionality is to be "ancient roots," then laws that discriminate on the basis of race, sex, alienage, national origin or illegitimacy ${ }^{122}$ will be similarly immune from constitutional attack. ${ }^{123}$ As the desegregation struggles demonstrated, social practices often represent political choices, and "what once was a 'natural' and 'self-evident' ordering later comes to be seen as an artificial and invidious constraint on human potential and freedom."124 This recognition places the United States at a painful crossroads. It can preserve its longstanding caste hierarchies, or it can preserve its longstanding commitment to equality. It cannot do both.

117. A. Bickel, supra note 112 , at 69 .

118. Watkins v. United States Army, 847 F.2d 1329, 1353 (Reinhardt, J., dissenting), reh'g en banc ordered, 847 F.2d 1362 (9th Cir. 1988). Accord Padula v. Webster, 822 F.2d 97, 103 (D.C. Cir. 1987); Gay \& Lesbian Students Ass'n v. Gohn, 656 F. Supp. 1045, 1057 (W.D. Ark. 1987), rev'd on other grounds, 850 F.2d 361 (8th Cir. 1988).

119. See supra note 12.

120. Watkins, 847 F.2d at 1355 (Reinhardt, J., dissenting).

121. Bowers, 478 U.S. at 192.

122. See Gity of Cleburne v. Gleburne Living Center, Inc., 473 U.S. 432, 440-41 (1985) (citing cases).

123. See, e.g., Davis v. County School Bd., 103 F. Supp. 337, 339 (E.D. Va. 1952) (statute requiring racially segregated schools does not violate Constitution, because segregation "has for generations been a part of the mores of [Virginia's] people."), rev'd sub nom. Brown v. Board of Educ., 347 U.S. 483 (1954); Plessy v. Ferguson, 163 U.S. 537, 550 (1896) (segregation law sustained as comporting with "the established usages, customs, and traditions of the people").

124. Cleburne, 473 U.S. at 466 (Marshall, J., concurring in the judgment in part and dissenting in part). 


\title{
Advertising and Title VIII: The Discriminatory Use of Models in Real Estate Advertisements
}

\author{
Margot S. Rubin
}

Many Americans begin the search for a new home by consulting newspaper advertisements and developers' brochures that describe in words and pictures the available housing and the surrounding community. Since 1968 , the content of these advertisements has been regulated by the Fair Housing Act. Section 3604(c) of the Fair Housing Act of 1968 (Title VIII of the Givil Rights Act of 1968) makes it unlawful

[t]o make, print, or publish, or cause to be made, printed or published any notice, statement, or advertisement, with respect to the sale or rental of a dwelling that indicates any preference, limitation, or discrimination based on race, color, religion, sex, or national origin, or an intention to make any such preference, limitation, or discrimination. ${ }^{1}$

Claimants have recently begun to utilize this provision more extensively. Plaintiffs have brought suits in Virginia, the District of Columbia, and New York alleging that the virtual exclusion of black models ${ }^{2}$ from real estate advertisements containing human models constitutes a violation of section 3604(c). So far, two decisions have been rendered. In Saunders v. General Services Corp., ${ }^{3}$ plaintiffs argued that the virtual absence of black models from the sixty-eight photographs contained in a developer's brochure indicated a preference based on race. ${ }^{4}$ In Spann v. Colonial Vil-

1. 42 U.S.C. $\S 3604$ (c) (1982). The Fair Housing Amendments Act, which become effective on March 12, 1989, modify this provision as follows: "Section 806 and subsections (c), (d), and (e) of section 804 [codified as $\S 3604$ ], are each amended by inserting 'handicap, familial status,' immediately after 'sex,' each place it appears." Fair Housing Amendments Act of 1988, § 6(b)(1), 134 CoNG. REc. H6491, H6492 (daily ed. Aug. 8, 1988). The Senate passed the Amendments on Aug. 2, 1988, 134 Cong. Rec. S10,562 (daily ed. Aug. 2, 1988), and the House concurred in the Senate version on Aug. 8, 1988, 134 Cong. Rec. H6501 (daily ed. Aug. 8, 1988). President Reagan signed the legislation on Sept. 13, 1988. N.Y. Times, Sept. 14, 1988, at A29, col. 2.

2. This Note will focus on the exclusion of black models since their absence was at issue in these cases but the discussion applies more generally to the exclusion of models representing any minority group.

3. 659 F. Supp. 1042 (E.D. Va. 1987).

4. Id. at 1049 . 
lage, Inc. ${ }^{5}$ plaintiffs alleged that the defendants' advertising campaigns in the Washington Post featuring exclusively white models violated the same provision of the Fair Housing Act. ${ }^{6}$ In both suits, the plaintiffs sought a declaratory judgment, injunctive relief, and damages to compensate individual plaintiffs and fair housing organizations for the injuries suffered as a result of the advertising. ${ }^{7}$

Two critical issues emerge from these cases. The first is whether plaintiffs must provide proof of discriminatory intent to establish a section 3604(c) violation. The decisions in Saunders and Colonial Village provide conflicting answers to this question, ${ }^{8}$ and few other cases have been

5. 662 F. Supp. 541 (D.D.C. 1987).

6. Id. at 542. Plaintiffs in Colonial Village and Saunders also alleged violations of 42 U.S.C. § 3604(a) and 42 U.S.C. $\$ \S 3601-3619$ respectively, and both alleged violations of $\$ 1981$ and 1982 of the Civil Rights Act, 42 U.S.C. $\S \S 1981,1982$ (1982). This Note will address only the $\S 3604$ (c) claims.

7. Saunders, 659 F. Supp. at 1059; Colonial Village, 662 F. Supp. at 542.

8. While cross-appeals in the Saunders case were settled leaving undisturbed the lower court holding that intent need not be shown, plaintiffs appealed the contrary decision in Colonial Village to the D.C. Circuit. The circuit court dismissed the appeal without prejudice for a lack of a final order under FED. R. Crv. F. 54(b) and 28 U.S.C. § 1291 (1982). Spann v. Colonial Village, Inc., No. 877118 (D.C. Cir. Apr. 6, 1988). Plaintiffs subsequently filed a motion in the district court seeking to obtain a final decision regarding co-defendant Mobile Land Development Corporation. Plaintiffs Motion For Order Entering Final Judgment at 1, Spann v. Colonial Village, Inc. (D.D.C.) (No. 862917) (filed May 17, 1988). The court held that service was properly effected on Mobile. Spann v. Colonial Village, Inc., No. 86-2917 (D.D.C. filed Oct. 13, 1988). Plaintiffs are proceeding with their appeal, and the D.C. Circuit will have the opportunity to consider Judge Greene's decision on intent. Id. at 2 . Several similar $\$ 3604$ (c) claims brought in the D.C. District Court had been stayed pending the outcome of the Colonial Village litigation. Spann v. Restec Corp., No. 87-1156 (D.D.C. filed Apr. 27, 1987); Spann v. Words \& Co., No. 87-1154 (D.D.C. filed Apr. 27, 1987); Spann v. Zoslow Assocs., No. 87-1155 (D.D.C. filed Apr. 27, 1987); Spann v. Carley Capital Group, No. 87-0054 (D.D.C. filed Jan. 12, 1987). The court subsequently issued a procedural decision intended to conserve the court's resources by discontinuing the stay, dismissing the cases without prejudice, and then entertaining a motion for reconsideration upon resolution of the Colonial Village appeal. Spann v. Carley Capital Group, No. 87-0054 (D.D.C. filed Sept. 30, 1988).

Even if the D.C. Circuit reverses the district court's ruling on intent, the issue probably will be contested in other jurisdictions where the discriminatory use of human models in real estate advertisements is currently being debated. On June 15, 1987, 28 complaints alleging violations of both Title VIII and New York state law were filed with the New York State Division of Human Rights and with the U.S. Department of Housing and Urban Development (HUD), challenging all-white human model advertisements for 28 different complexes that appeared in the Sunday Real Estate section of the New York Times. In approximately half of these cases, the New York State Division of Human Rights also filed complaints challenging the advertisements under the New York Human Rights Law. K. Scanlon, Washington Lawyers' Committee for Civil Rights Under Law, Facts about New York Cases (July 15, 1988) (hereinafter New York Gase Summary] (on file at Yale Law Journal) (facts concerning pending New York complaints challenging all-white model advertisements). Four lawsuits have also been filed in the Southern District of New York to preserve the federal claims. Ragin v. Gala Realty, No. 88 Civ. 2300 (S.D.N.Y. filed Apr. 1, 1988); Ragin v. Rams Mktg., Inc., No. 88 Civ. 2301 (S.D.N.Y. filed Apr. 1, 1988); Ragin v. Manhattan Mktg., Inc., No. 88 Civ. 0478 (S.D.N.Y. filed Jan. 22, 1988); Ragin v. Steiner, Clateman \& Assocs., No. 87 Civ. 9028 (S.D.N.Y. filed Dec. 18, 1987). These cases have been put on suspense status pending the outcome of conciliation efforts. New York Gase Summary. Negotiations were also begun with the New York Times in an effort to reach an agreement to adopt a policy on integrated human model advertisements similar to the one adopted by the Washington Post requiring that at least $25 \%$ of the models portrayed in real estate advertisements be black models. Id. See Letter from Boisfeuillet Jones, Jr., Vice President and Counsel of the Washington Post, to Kerry Alan Scanlon (Aug. 4, 1986) (agreement reached in settlement of real estate advertisement claims) (on file at Yale Law Journal); Bias Suit Over Housing Ads By 2 Local Firms Dismissed, Wash. Post, May 23, 1987, at C1, col. 4. 
decided in the federal courts under section $3604(\mathrm{c}) .^{9}$ This Note will argue that the language of section 3604(c), the legislative history of Title VIII, and the relevant decisions all suggest that no showing of discriminatory intent is required.

The second emerging issue is how courts will grapple with the fundamental problem facing plaintiffs in this new type of litigation-how to establish that a given human model advertising campaign "indicates a racial preference." Even if no showing of intent is required, plaintiffs must still make a showing sufficient to constitute a valid claim of discriminatory advertising under section 3604(c). Because of this burden, the federal courts must now consider what types of proof are appropriate and sufficient to establish a section 3604(c) claim. Drawing on the few court decisions involving section 3604(c), this Note supports the "ordinary reader" standard developed in United States v. Hunter ${ }^{10}$ and applied in Saun$d e r s^{11}$ as a solution to the problem of proof.

\section{Recognition of the Gause of Action}

Courts have recognized a private cause of action ${ }^{12}$ based on the discriminatory use of models. The Saunders court recognized that the alleged discriminatory advertising practice constituted a valid cause of action under section 3604(c), and the Colonial Village court assumed arguendo that the plaintiffs presented a valid claim. ${ }^{13}$ Moreover, in the mid-1970s, five human model advertising complaints were filed by the Housing Opportunities Council of Metropolitan Washington. A settlement was reached before a civil action was filed in four of these cases. ${ }^{14}$ In the fifth

9. See, e.g., United States v. Hunter, 459 F.2d 205, 215 (4th Cir.), cert. denied, 409 U.S. 934 (1972); United States v. Gilman, 341 F. Supp. 891 (S.D.N.Y. 1972); Holmgren v. Little Village Community Reporter, 342 F. Supp. 512 (N.D. Ill. 1971). See also infra Section IID.

10. 459 F.2d 205, 215 (4th Cir.), cert. denied, 409 U.S. 934 (1972).

11. Saunders, 659 F. Supp. at 1058.

12. According to the procedures outlined in the Fair Housing Act, $\S 3604$ (c) may be enforced by private persons bringing civil actions in federal district courts. 42 U.S.C. $\$ 3612$ (c) (1982). No miminum amount in controversy is required, but the action must be filed within 180 days of the occurrence of the alleged discriminatory housing practice. 42 U.S.C. $\S 3612$ (a). This 180-day statute of limitations period was the focus of the Colonial Village decision. The court held that the plaintiffs had not shown a violation within the relevant statute of limitations period. 662 F. Supp. at 546-47. The court's more recent Memorandum and Order suggests, however, that the court may have modified its view regarding the statute of limitations. Spann v. Colonial Village, Inc., No. 86-2917, slip. op. at 6 (D.D.C. filed Oct. 13, 1988) ("Only the last asserted occurrence of a practice of racial preference need be in that 180 day period. . . . [T] he last of defendants' all-white ads was published within the 180-day limitations period. . .").

The Fair Housing Amendments Act of 1988 significantly alters these enforcement provisions. Under the new law, not only can private persons bring causes of action, but, if the Secretary determines that "reasonable cause" exists to believe that the statute has been violated, the Secretary must issue a charge on behalf of the alleged victim. Fair Housing Amendments Act of $1988, \S 8(\mathrm{~g})(2)(\mathrm{A})$, 134 Cong. Rec. H6494 (daily ed. Aug. 8, 1988). In addition, the Amendments extend the statute of limitations period, allowing plaintiffs one year to file a complaint with HUD, and two years to file a suit in federal court. Id. at H6493-96.

13. Colonial Village, 662 F. Supp. at 542; Saunders, 659 F. Supp. at 1053.

14. Housing Opportunities Council of Metro. Washington v. Carl Freeman Assocs., Inc., No. 
case, Housing Opportunities Council of Metropolitan Washington $v$. Yeonas Co., ${ }^{15}$ the district court implicitly recognized that this type of claim represented a valid cause of action by denying a motion for summary judgment. ${ }^{16}$ The case was subsequently settled before trial. In another case, ${ }^{17}$ a district court entered a consent order expressly requiring the continued use of human models "in a substantial portion of [defendant's] display advertising."18 This provides further evidence that the provisions of Title VIII apply to the discriminatory use of human models in real estate advertisements.

Perhaps the strongest evidence for finding a cause of action in these cases is presented by the pertinent United States Department of Housing and Urban Development (HUD) regulations. HUD is "the federal agency primarily assigned to implement and administer Title VIII."19 Pursuant to its statutory rulemaking authority, ${ }^{20}$ HUD has promulgated regulations to "assist all advertising media, advertising agencies and all other persons who use advertisements in complying with the proscriptions against discrimination in advertising in Title VIII."21 These regulations were first issued as guidelines in 1972..22 The Supreme Court has indicated that the agency's interpretation of its guidelines should be accorded considerable deference by the courts when considering Fair Housing Act claims. ${ }^{23}$

HUD reissued the guidelines as substantive regulations in 1980 "in or-

824-H-416; Housing Opportunities Council of Metro. Washington v. Ryan Homes, No. 824-H-634; Housing Opportunities Council of Metro. Washington v. Gulf-Reston, Inc., No. 851-H-376; and Housing Opportunities Council of Metro. Washington v. Marvin Gerstein Advertising Agency, No. 824-H-635. See Scanlon, A Report on the Committee's Fair Housing Project 1975 1983, 27 How. L.J. 1457, 1459-60 (1984) (report on status of housing litigation brought by Washington Lawyers' Committee for Civil Rights).

15. No. 74-1269 (D.D.C. 1974). See Scanlon, supra note 14, at 1460 n.5.

16. Scanlon, supra note 14 , at 1460 n.5.

17. NAACP v. ITT Community Dev. Corp., 399 F. Supp. 366 (D.D.C. 1975).

18. Id. at 368.

19. Gladstone Realtors v. Village of Bellwood, 441 U.S. 91, 107 (1979).

20. 42 U.S.C. $\$ \S 3535,3608$ (1982 \& Supp. III 1985).

21. Fair Housing Advertising Guidelines, 45 Fed. Reg. 57,102 (1980) (final rule).

22. Advertising Guidelines for Fair Housing, 37 Fed. Reg. 6700 (1972).

23. See Gladstone Realtors, 441 U.S. at 107; Trafficante v. Metropolitan Life Ins. Co., 409 U.S. 205, 210 (1972). The Hunter court cited the HUD advertising guidelines in support of its decision. 459 F.2d at 215 n.11. See also infra note 25 and accompanying text. The Colonial Village court, however, found the human model regulations less than binding. The regulations describe HUD's authority to investigate complaints and refer them to the Attorney General for action; the implementation of the policies contained in the regulations is to be considered by the Assistant Secretary of HUD investigating complaints as evidence of compliance with $\S 3604$ (c). 24 C.F.R. $\S 109.30$ (1987). The court in Colonial Village emphasized this distinction and concluded: "The regulations not only do not purport to, and they do not, apply to litigation in court, but they fail entirely to provide authority regarding the parameters of $\S 3604$ (c) when that provision is involved in the context of such litigation." 662 F. Supp. at 545. However, the court appeared to alter its view of these regulations in its more recent Memorandum and Order. "Defendants do not cite any case law that these regulations are not intended to have the force of law or to govern in this litigation. The regulations are of course entitled to substantial deference by the court when interpreting the Fair Housing Act, Gladstone Realtors v. Village of Bellwood, 441 U.S. 91, 107 (1979). . . "Spann v. Colonial Village, Inc., No. 86-2917, slip op. at 6 (D.D.C. filed Oct. 13, 1988). 
der to attain better enforcement and to assure consistency in obtaining compliance with section 804(c) [now renumbered 3604]."24 Courts have held that regulations such as these which are published in the Code of Federal Regulations are not mere statements of policy, but are regulations " "having general applicability and legal effect." "25

Regarding the race of human models, the HUD regulations state:

Human models in photographs, drawings, or other graphic techniques may not be used to indicate exclusiveness on the basis of race, color, religion, sex, or national origin. If models are used in display advertising campaigns, the models should be clearly definable as reasonably representing majority and minority groups in a metropolitan area and both sexes. Models, if used, should portray persons in an equal social setting and indicate to the general public that the housing is open to all without regard to race, color, religion, sex, or national origin, and is not for the exclusive use of one such group. ${ }^{2 B}$

In addition, the regulations provide: "A failure by persons placing advertisements to comply with the provisions in this part when found in connection with the investigation of a complaint alleging the making or use of discriminatory advertisements will be a basis for concluding that a violation of section 804 has occured."27 These regulations clearly put housing advertisers on notice that section 3604(c) regulates the use of human models in real estate advertisements, and that failure to comply with these regulations constitutes a basis for finding a violation of the Fair Housing Act. ${ }^{28}$

\section{The Absence of an Intent Requirement in Section 3604(c)}

The court in Saunders held that "[i]n order to prove a violation of this subsection [3604(c)], plaintiffs need not establish that defendants intended to express a racial preference." ${ }^{29}$ Applying the ordinary reader standard,

24. Fair Housing Advertising Guidelines, 45 Fed. Reg. 57,102 (1980) (final rule).

25. Brock v. Cathedral Bluffs Shale Oil Co., 796 F.2d 533, 539 (D.C. Cir. 1986) (emphasis in original). See also Chevron U.S.A., Inc. v. Natural Resources Defense Council, Inc., 467 U.S. 837, 844-45 (courts must defer to any reasonable construction of a statute by an administering agency as long as that constriction does not contravene clear intent of Congress). In other contexts, courts have ruled that HUD regulations have the force and effect of law. See, e.g., Blackshear Residents Org. v. Housing Auth. of Austin, 347 F.Supp. 1138, 1145 (W.D. Tex. 1972) (HUD regulation governing site selection of public housing projects has force of law).

26. 24 C.F.R. \& 109.30(b) (1987).

27. 24 C.F.R. $\S 109.16(\mathrm{a})(2)$ (1987).

28. See also United States v. Long, Eq. Opportunity in Hous. Rep. (P-H) I 13,631, at 14,091 (D.S.C. 1974) (use in real estate advertisements of locally understood words or phrases "which imply or suggest race or color is presumptively illegal" under the HUD guidelines), remanded on other grounds, 537 F.2d 1151 (5th Cir. 1975), cert. denied, 429 U.S. 871 (1976). Another section of the Code of Federal Regulations reiterates this prohibition on the discriminatory use of models in advertisements. See 12 C.F.R. $\$ 338.2$ (1987) (prohibiting discriminatory advertising by banks in promoting loans).

29. 659 F. Supp. at 1058. 
the court held that the almost exclusive use of white models in this context had a discriminatory meaning for potential black tenants and therefore violated section $3604(c) .{ }^{30}$ The Colonial Village court, however, stated "that absent a showing of intent to indicate a racial preference or of other extrinsic circumstances revelatory of a racial preference, real estate advertisements do not violate the Fair Housing Act merely because models of a particular race are not used in one ad or a series of ads." ${ }^{\text {"31 }}$ As a result of these two conflicting district court decisions, the question whether a plaintiff must show discriminatory intent to establish a violation of section 3604(c) must be considered.

\section{A. The Statutory Language of Section 3604(c)}

The statutory language of section 3604(c) does not explicitly state whether a showing of intent is necessary to establish a violation. However, both the terms of the provision and the broad interpretation the Supreme Gourt has given to Fair Housing Act claims suggest that no such showing is necessary.

First, section 3604(c) is written in disjunctive form; the statute prohibits any advertisement "that indicates any preference ... or discrimination based on race . . or an intention to make any such preference . . ."32 Since only the latter clause of the subsection mentions intent, it is arguable that the remainder of the provision proscribes some forms of unintentional conduct. In addition, section 3604(c) prohibits any advertisement, notice, or statement that "indicates" a racial preference. The choice of this broad word (instead of "states" or merely "discriminates") may reflect Congress' desire to establish a strict liability standard in this provision, particularly since it is the advertisement, not the advertiser, that so "indicates." The most obvious explanation for the choice of terms is the difficulty of proving an intent to discriminate in this context. ${ }^{33}$ The word "indicates" was broadly construed in United States $v$. Long ${ }^{34}$ where the court concluded that the defendant's use of the phrase "any qualified buyer" violated section 3604(c) since that phrase was apparently used to alert readers that the advertised properties were available to blacks. ${ }^{36}$ The court held that the use in real estate advertisements of locally understood

30. Id.

31. 662 F. Supp. at 546 .

32. 42 U.S.C. $\$ 3604$ (c) (1982) (emphasis added).

33. See infra Section III. Similar standards have been adopted by Congress in other areas of antidiscrimination law in order to ease the burden of proof. See, e.g., United States v. Bethlehem Steel Corp., 446 F.2d 652, 662 (2d Cir. 1971) (Title VII); Voting Rights Act $\$ 2,42$ U.S.C. § 1973 (1982).

34. United States v. Long, Eq. Opportunity in Hous. Rep. (P-H) \I 13,631, at 14,091 (D.S.C. 1974), remanded on other grounds, 537 F.2d 1151 (5th Cir. 1975), cert. denied, 429 U.S. 871 (1976).

35. Id. at $14,089-91$. 
words or phrases "which imply or suggest race or color is presumptively illegal" under the HUD guidelines. ${ }^{36}$

Second, Congress' purpose in enacting the Fair Housing Act was "to provide, within constitutional limitations, for fair housing throughout the United States." ${ }^{37}$ Many courts, including the Supreme Court, have held that Title VIII must be construed broadly to achieve this purpose. The first Title VIII case decided by the Court, Trafficante v. Metropolitan Life Insurance, ${ }^{38}$ expounded this need for a broad interpretation of Title VIII. In Trafficante, the Court described the language of the Fair Housing Act as "broad and inclusive." 38 Lower courts have consistently interpreted Trafficante and the Act's own statement of purpose "as directives to give the statute the broadest possible interpretation."40

Third, while it could be argued that the inclusion of the phrase "because of race" in sections $3604(a)$ and (b) of Title VIII ${ }^{41}$ demands a showing of intent, ${ }^{42}$ the phrase has not been read so restrictively. Some courts have rejected the view that a party cannot commit an act "because of race" unless she intends to discriminate. Instead, these courts have adopted a broader, outcome-oriented view that a party commits an act "because of race" whenever the natural and foreseeable consequence of that act is to discriminate between races, regardless of intent. ${ }^{43}$

In addition, the Supreme Court has only adopted this narrow interpretation of the language when considering constitutional claims. ${ }^{44}$ The

36. Id. at 14,091 .

37. 42 U.S.C. $\$ 3601$ (1982).

38. 409 U.S. 205 (1972).

39. Id. at 209.

40. R. Schwemm, Housing Discrimination Law 42 (1983). See also Metropolitan Hous. Dev. Corp. v. Village of Arlington Heights, 558 F.2d 1283, 1289 (7th Cir. 1977), cert. denied, 434 U.S. 1025 (1978); Resident Advisory Bd. v. Rizzo, 564 F.2d 126, 147 (3d Cir. 1977), cert. denied, 435 U.S. 908 (1978).

41. 42 U.S.C. $\$ 3604$ (a) makes it unlawful "[t]o refuse to sell or rent after the making of a bona fide offer, or to refuse to negotiate for the sale or rental of, or otherwise make unavailable or deny, a dwelling to any person because of race, color, religion, sex, or national origin." (emphasis added). 42 U.S.C. $\$ 3604$ (b) makes it unlawful "[t]o discriminate against any person in the terms, conditions, or privileges of sale or rental of a dwelling, or in the provision of services or facilities in connection therewith, because of race, color, religion, sex, or national origin." (emphasis added). Section (c) uses the phrase "based on race" rather than "because of race," but this difference is required by the grammatical construction, and does not justify using a different standard of intent.

42. The Supreme Court adopted this narrow view for equal protection purposes in Washington v. Davis, 426 U.S. 229 (1976). The Court's decision in Davis has generated a great deal of scholarly literature examining the requirement of discriminatory intent in constitutional cases. See, e.g., Bell, Foreword: Equal Employment Law and the Continuing Need for Self-Help, 8 LoY. U. CHI. L.J. 681 (1977); Freeman, Legitimizing Racial Discrimination Through Antidiscrimination Law: A Critical Review of Supreme Court Doctrine, 62 MINN. L. REv. 1049 (1978); Karst, Foreword: Equal Citizenship Under the Fourteenth Amendment, 91 HARv. L. REv. 1 (1977); Lawrence, The Id, the Ego, and Equal Protection: Reckoning with Unconscious Racism, 39 STAN. L. REv. 317 (1987).

43. See Metropolitan Hous. Dev. Corp. v. Village of Arlington Heights, 558 F.2d 1283, 1288 (7th Cir. 1977), cert. denied, 434 U.S. 1025 (1978); Resident Advisory Bd. v. Rizzo, 564 F.2d 126, 147 (3d Cir. 1977), cert. denied, 435 U.S. 908 (1978).

44. In both housing and employment discrimination cases brought under the equal protection clause, the Supreme Court requires a showing of discriminatory intent. See Village of Arlington Heights v. Metropolitan Hous. Dev. Corp., 429 U.S. 252 (1977) (housing); Washington v. Davis, 426 
phrase "because of race" has been understood in other contexts to require no showing of intent. In Griggs v. Duke Power Co., ${ }^{45}$ the Supreme Court did not narrowly construe the phrase "because of race" contained in section 703(h) of Title VII to require proof of discriminatory intent to establish a violation of the provision. Instead, the Court focused on Congress' purpose in enacting Title VII-namely the achievement of equal employment opportunity-and interpreted Title VII broadly to implement that purpose, holding that any employment practice that operates to exclude blacks and cannot be shown to relate to job performance is prohibited regardless of the intent of the parties. ${ }^{46}$ The same phrase in Title VIII, a parallel provision of the Civil Rights Act, should be interpreted in the same manner. ${ }^{47}$

\section{B. The Legislative History of the Fair Housing Act}

The legislative history of the Fair Housing Act is somewhat sparse, but the available record does suggest that Congress did not seek to require a showing of intent to establish a violation. While Congress considered fair housing legislation for more than two years, Title VIII itself was the subject of relatively little debate. The legislation was enacted based on Senator Dirksen's floor amendment, and the committee reports and other documents which usually accompany major legislation are not available in this instance. Neither the House Judiciary Committee Report ${ }^{48}$ nor the Senate Judiciary Committee Report ${ }^{49}$ addressed the issue of fair housing because a fair housing provision was not included in the 1967 legislation. ${ }^{\text {so }}$ As a result, the legislative history of Title VIII must be gleaned primarily from the congressional floor debates, especially the debates in the Senate.51

During the floor debate prior to the passage of the Act, Senator Baker introduced an amendment that would have required proof of discriminatory intent to establish a Title VIII claim. ${ }^{52}$ Under Baker's proposal, ${ }^{53}$ a

U.S. 229 (1976) (employment).

45. 401 U.S. 424 (1971).

46. Id. at 431 .

47. See Comment, Applying the Title VII Prima Facie Case to Title VIII Litigation, 11 Harv. C.R.-C.L. L. REv. 128 (1976) (arguing that requiring proof of specific intent is too confining and that doctrine of prima facie case applied to Title VII litigation should also be used to evaluate Title VIII claims).

48. H.R. ReP. No. 473, 90th Cong., 2d Sess. 2 (1967).

49. S. Rep. No. 721,90 th Cong., 2d Sess. 1, reprinted in 1968 U.S. Code Cong. \& Admin. News 1837.

50. Only the Subcommittee on Housing and Urban Affairs of the Senate Committee on Banking and Currency held hearings to consider similar fair housing legislation proposed by Senator Mondale. See Hearings on S. 1358, S. 2114, and S. 2280 Before the Subcomm. on Housing and Urban Affairs of the Senate Comm. on Banking and Currency, 90th Cong., 1st Sess. 197 (1967).

51. It should be noted that $\S 3604(\mathrm{c})$ was never specifically mentioned during the congressional floor debate. For a general discussion of the legislative history of Title VIII, see Dubofsky, Fair Housing: A Legislative History and a Perspective, 8 WASHBURN L.J. 149 (1969); R. SCHWEMM, supra note 40 , at $32-36$.

52. 114 Cong. Rec. 5214 (1968).

53. Senator Baker's amendment did not focus on $\S 3604$. Nonetheless, the Third Circuit included 
homeowner would violate the Fair Housing Act only if she specifically instructed a real estate agent to discriminate. Many Senators objected to the proposal. Senator Percy forcefully argued that proof of a specified racial preference to establish a violation of Title VIII "would be impossible to produce." ${ }^{\prime 54}$ Senator Mondale, the original sponsor of the Fair Housing Act, offered specific examples of the potential difficulty of meeting this burden of proof. "[I]n a case in which the seller and his agent agree to discriminate, but do not do so in writing or in some other tangible form of outside evidence, there would be no way to prove that they in fact had violated the amendment." ${ }^{\text {"ss }}$ After an extensive debate of this issue, the Senate rejected Baker's amendment ${ }^{56}$ and thereby declined to adopt an intent requirement. These events support the conclusion that Congress did not seek to require a showing of intent to establish a violation of the statute.

\section{Intent Not Required in Previous Section 3604(c) Cases}

While there is an apparent conflict as to whether intent is required in cases alleging the discriminatory use of models in real estate advertisements, most courts ruling on other section 3604(c) claims closely follow the statute and require only that the challenged statement "indicates a racial preference." In Mayers $v$. Ridley, ${ }^{57}$ the D.C. Circuit directly addressed the question of whether section 3604(c) requires a showing of intent. In that case, the court held that the filing of instruments containing racially restrictive covenants by the Recorder of Deeds for the District of Columbia is prohibited by Title VIII, regardless of the Recorder's intent. ${ }^{\mathrm{B}}$ "Whether he [the Recorder] has thought of it before or not, when the Recorder [of Deeds] publishes the notice of the sale of a dwelling, i.e., records a deed containing discriminatory racial covenants for the world to see, he is engaging in an act unlawful under $\S 3604$ (c). . . ."58 Similarly, in United States $v$. Hunter, ${ }^{60}$ the leading case involving section $3604(\mathrm{c}),{ }^{61}$

a discussion of this aspect of the legislative history in construing $\S 3604$. See Resident Advisory Bd. v.

Rizzo, 564 F.2d 126, 147 (3d Cir. 1977), cert. denied, 435 U.S. 908 (1978).

54. 114 CoNG. ReC. 5216 (1968).

55. Id. at 5218 .

56. The Senate vote on Baker's amendment was 43 yeas and 48 nays. Id. at 5221-22.

57. 465 F.2d 630 (D.C. Cir. 1972) (per curiam) (en banc).

58. Id.

59. Id. at 650 (Wilkey, J., concurring) (emphasis added). But see Woodward v. Bowers, $630 \mathrm{~F}$. Supp. 1205 (M.D. Pa. 1986) (Recorder of Deeds did not violate Title VIII by accepting deed with racially restrictive covenant).

60. 459 F.2d 205 (4th Cir.), cert. denied, 409 U.S. 934 (1972).

61. Hunter involved an action to enjoin a newspaper from publishing advertisments that were allegedly discriminatory. The Fourth Circuit's opinion addressed several significant issues relating to $\$ 3604$ (c). First, the court held that the language of the statute makes it clear that Congress intended that the statute apply to newspapers and other media carrying discriminatory advertisements, even though someone else may have drafted and placed the advertisement. 459 F.2d at 210 . Second, the court upheld the constitutionality of the statute, describing the Act as a valid exercise of Congress' 
the Fourth Circuit held that the appearance of advertisements stating that apartments were available in a "white only" home indicated a racial preference and therefore violated the Fair Housing Act. ${ }^{62}$

Despite the fact that an intentional discriminator was involved in both Mayers and Hunter, no showing of discriminatory intent was required in either case. A Texas district court succinctly summarized the state of the law in February, 1987: "The prevalent interpretation of 42 U.S.C. $\S$ 3604(c) requires no discriminatory intent for a violation to occur."

\section{Section 3604 and the Discriminatory Effects Standard}

While few courts have directly considered the construction and application of the terms of section 3604(c), ${ }^{64}$ many circuit courts have considered the broad issue of whether a showing of intent is necessary to establish a Title VIII violation when a facially neutral act is challenged. ${ }^{65}$ These decisions have involved section 3604 generally, or sections 3604(a) and (b), but not (c). ${ }^{66} \mathrm{~A}$ review of this related case law supports the argument that no showing of discriminatory purpose is required.

Many of the decisions concerning section 3604 have involved cases where the challenged housing practice appears neutral on its face but is alleged to be discriminatory. In these cases, courts have been forced to consider whether plaintiffs must prove discriminatory intent, or if only discriminatory effect must be shown. They have responded with a prima facie "impact" or "effects" test, ${ }^{67}$ first developed by the Eighth Circuit in

power under the Thirteenth Amendment to eliminate the badges and incidents of slavery. Id. at 214. Third, the court concluded that $\S 3604$ (c) did not violate the First Amendment. Id. at 211 .

'First Amendment concerns were mentioned by the court in Colonial Village, 662 F. Supp. at 546, and will probably appear in future litigation challenging the discriminatory use of models. As the court in Colonial Village recognized, upholding the plaintiffs' claims in these cases raises the "problem of the chilling effect of such burdens on advertisers' ability and desire to advertise . . . ." Id. Advertisers may be chilled from showing any models in their advertisements or feel compelled to include at least one model representing each minority in the community. Id. at 545. Although the Fourth Circuit's analysis of the First Amendment issue in Hunter was based on Valentine v. Christensen, 316 U.S. 52 (1941), which preceded the recent Supreme Court commercial speech decisions, its conclusion is probably still correct. The Court has reaffirmed its holding in Pittsburgh Press Co. v. Pittsburgh Comm'n on Human Relations, 413 U.S. 376 (1973), and has refused to extend First Amendment protection to commercial speech related to illegal activity. See Hoffman Estates v. Flipside, Hoffman Estates, Inc., 455 U.S. 489, 496 (1982) ("government may regulate or ban entirely" commercial speech "proposing an illegal transaction").

62. 459 F.2d at 214.

63. United States v. University Oaks Civic Club, 653 F. Supp. 1469, 1475 (S.D. Tex. 1987) (isolated and sporadic recording of deeds with racially restrictive covenants not pattern of discriminatory conduct in violation of Title VIII).

64. See supra note 9 .

65. A showing of discriminatory effect is required only in cases involving challenges to facially neutral acts; no showing of effect or intent is required in cases involving facially discriminatory conduct. See infra notes 84-85 and accompanying text.

66. For the text of subsections (a) and (b) of $\$ 3604$, see supra note 41.

67. Under prima facie analysis, plaintiffs must prove that the defendant's housing practice has had a discriminatory effect. The burden then shifts to the defendant to show that the practice is justifiable on other, nonracial grounds. If the prima facie inference of discrimination is not satisfactorily explained by the defendant, a violation is established. See R. Schwemm, supra note 40, at 61. See 
Williams v. Matthews Co. ${ }^{68}$ Williams held that a developer's facially neutral policy of selling lots in a subdivision only to approved builders operated to exclude blacks from acquiring lots in the subdivision and was prima facie discriminatory ${ }^{88}$ The Williams court held that no showing of discriminatory intent was necessary to establish a violation, ${ }^{70}$ and that the concept of "prima facie case" applies to housing discrimination "as much as it does to discrimination in other areas of life."'11

Later that same year in United States v. City of Black Jack, ${ }^{72}$ the Eighth Circuit offered a more detailed explanation of how this effectoriented prima facie standard should be applied to Fair Housing Act claims:

To establish a prima facie case of racial discrimination, the plaintiff need prove no more than that the conduct of the defendant actually or predictably results in racial discrimination; in other words that it has a discriminatory effect. The plaintiff need make no showing whatsoever that the action resulting in racial discrimination in housing was racially motivated. Effect, and not motivation, is the touchstone, in part because clever men may easily conceal their motivations, but more importantly, because ". . . whatever our law was once, ... . we now firmly recognize that the arbitrary quality of thoughtlessness can be as disastrous and unfair to private rights and the public interest as the perversity of a willful scheme."73

The Seventh Circuit's landmark decision in Metropolitan Housing Development Corp. v. Village of Arlington Heights ${ }^{74}$ presents the most con-

also Texas Dep't of Community Affairs v. Burdine, 450 U.S. 248 (1981) (clarifying requirements set forth in McDonnell Douglas Corp. v. Green, 411 U.S. 792 (1973), to prove a prima facie case of discrimination in Title VII cases). While the ordinary reader standard advocated by this Note might be described by a layman in terms of the "effect" or "impact" on the ordinary reader, the standard is not a variant of the "impact" or "effects" tests which are terms of art in housing law.

68. 499 F.2d 819 (8th Cir.), cert. denied, 419 U.S. 1021 (1974). This case involved alleged violations of $\S 3604$ (a) and (b), not (c), but the court referred generally to $\S 3604$ in its decision. 499 F.2d at 826 .

69. Id. at $826-27$.

70. Id.

71. Id.

72. 508 F.2d 1179 (8th Cir. 1974), cert. denied, 422 U.S. 1042 (1975). Plaintiffs alleged violations of $\S 3604(\mathrm{a})$, not (c).

73. 508 F.2d at 1184-85 (quoting Hobson v. Hansen, 269 F. Supp. 401, 497 (D.D.C. 1967), affd sub nom. Smuck v. Hobson, 408 F.2d 175 (D.C. Cir. 1969) (en banc)) (citations omitted) (emphasis added). The Eighth Circuit has continued to use a prima facie standard to evaluate Title VIII claims. See Wharton v. Knefel, 562 F.2d 550 (8th Cir. 1977) (following Williams and Black Jack to hold that black renter had been denied apartment because of racial discrimination in violation of Title VIII). The Second and Ninth Circuits also use the prima facie standard to evaluate Title VIII claims. See Robinson v. 12 Lofts Realty, Inc., 610 F.2d 1032 (2d Cir. 1979) (black plaintiff met prima facie burden in showing that defendant corporation refused to permit him to purchase cooperative apartment because of race); Halet v. Wend Inv. Co., 672 F.2d 1305, 1311 \& n.6 (9th Gir. 1982) (plaintiff met prima facie burden by showing discriminatory effect of defendant's adults-only rental policy).

74. 558 F.2d 1283 (7th Cir. 1977), cert. denied, 434 U.S. 1025 (1978) [hereinafter Arlington Heights $I I]$. 
vincing evidence that no showing of intent is required to establish that facially neutral conduct violates Title VIII. Plaintiffs brought suit to compel the village of Arlington Heights to rezone their property to permit construction of federally financed low-cost housing, alleging that the village's refusal to rezone the property was racially discriminatory. After trial, the district court held that the refusal to rezone was motivated by a desire to protect property values and maintain the prevailing zoning plan, not by a desire to discriminate racially ${ }^{75}$ The Seventh Circuit reversed, holding that despite the village's lack of discriminatory intent in its refusal to rezone, the "ultimate effect" of the refusal was discriminatory and therefore violated the equal protection clause. ${ }^{76}$ The Supreme Court granted certiorari and resolved the constitutional issue, holding that under Washington v. Davis, a showing of discriminatory intent is a prerequisite to establishing a violation of the equal protection clause. Since the Seventh Circuit had affirmed the district court's finding that there was no discriminatory intent behind the village's actions, the Supreme Court reversed. But the Court remanded the case to the Seventh Circuit for consideration of the plaintiff's Title VIII claims, implying that a showing of proof different from that necessary for equal protection claims governs Title VIII violations. ${ }^{77}$

On remand in Arlington Heights II, the Seventh Circuit focused only on whether the village's refusal to rezone violated the Fair Housing Act because the action had a discriminatory effect. Relying on the Supreme Court's holding in Griggs v. Duke Power Co. ${ }^{78}$ that a prima facie case of employment discrimination could be established under Title VII without a showing of discriminatory intent, the Seventh Circuit held that this Title VII standard should be applied to at least some Title VIII claims. ${ }^{79}$ Like the drafters of the provision, ${ }^{80}$ the court recognized the difficulty of proving intent in Fair Housing Act claims and instead adopted an impact standard. In the case before it, the Seventh Circuit held that the village's refusal to rezone violated section 3604(a) even though no discriminatory intent was shown. ${ }^{81}$

All the circuit courts which have considered this issue agree with the

75. 373 F. Supp. 208, 211 (N.D. Ill. 1974).

76. 517 F.2d 409, 412-15 (7th Cir. 1975).

77. 429 U.S. 252, 268-71 (1977). See also Resident Advisory Bd. v. Rizzo, 564 F.2d 126, 147 (3d Cir. 1977) ("In remanding, rather than directing the dismissal of the Arlington Heights litigation, the Court at least implied that considerations other than those necessary for proof of equal protection violations must govern Title VIII claims."), cert. denied, 435 U.S. 908 (1978).

78. 401 U.S. 424 (1971). See supra notes $44-45$ and accompanying text.

79. Arlington Heights $I I, 558$ F.2d at $1289-90$.

80. See supra text accompanying notes 52-56.

81. Shortly after the Seventh Circuit's decision in Arlington Heights II, the Third Circuit addressed the same issue in Resident Advisory Bd. v. Rizzo. There, the Third Circuit recognized the distinction between the constitutional and Title VIII claims made in Arlington Heights $I I$ and held, as did the Seventh Circuit, that only constitutional claims require a showing of discriminatory purpose. 564 F.2d at 147. 
Seventh Circuit that to challenge facially neutral conduct, a plaintiff may show either discriminatory effect or discriminatory intent to establish a section 3604 (a) or (b) violation. ${ }^{82}$ But these decisions do not impose an obligation to show discriminatory effect when the plaintiff is challenging a practice that is discriminatory on its face. A distinction must be drawn between cases involving facially neutral acts, like Arlington Heights II, and those involving facially discriminatory acts. For example, if it were shown that a landlord required blacks to provide more evidence of ability to pay or more references than whites, that discriminatory practice would, by itself, violate section 3604 (b).$^{83}$ Similarly, a showing of discriminatory effect is not necessarily required to establish liability under section 3604(c). Thus, if an advertisement were to state "blacks not wanted," it would violate section 3604(c) in and of itself, just as an advertisement for apartments in a "white only" home would. ${ }^{84}$ Likewise, a long-running advertisement campaign that continually uses only white models in a metropolitan area that has a significant black or other minority population, on its face, "indicates [a] preference, limitation, or discrimination based on race."85 Plaintiffs should not be required to prove the "discriminatory effect" of these advertisements; they should only be required to show that the advertisements convey a discriminatory message to minority readers. To assess how a plaintiff can meet this burden in a particular case, the use of human models in advertisements must be considered.

\section{E. The Significance of the Use of Models in Advertisements}

Advertisers design advertisements using human models so that targeted consumers will identify positively with the models in the advertisement and buy the product. ${ }^{86}$ Advertisers carefully choose the models to be featured because "[i]f the viewer likes the people in the scene, and if there is someone in the illustration he might like to be, this produces positive re-

82. See cases cited supra notes 73, 81. See also Arthur v. City of Toledo, 782 F.2d 565 (6th Cir. 1986) (following other circuit court decisions and finding that plaintiffs could succeed under the Fair Housing Act by showing discriminatory effect); United States v. Pelzer Realty Co., 484 F.2d 438 (5th Cir. 1973) (refusal to sell homes to blacks and discrimination against blacks in terms and conditions violates Title VIII regardless of intent), cert. denied, 416 U.S. 936 (1974); Mayers v. Ridley, 465 F.2d 630, 650 (D.C. Cir. 1972) (per curiam) (en banc) (filing of instruments containing racially restrictive covenants violates Title VIII regardless of Recorder's intent). In the most significant recent decision in this area, Betsey v. Turtle Creek Assocs., 736 F.2d 983 (4th Cir. 1984), the Fourth Circuit held that the defendant's all-adult rental policy had a discriminatory effect on minorities in violation of $\S 3604$. The Fourth Circuit's opinion only addressed the question of discriminatory effect; the district court's holding that defendants had successfully rebutted plaintiff's proof of discriminatory intent was not challenged. In sum, the 10 circuit courts to consider this issue have all adopted the same position. The First and Tenth Circuits have not yet addressed this question.

83. See, e.g., United States v. Pelzer Realty Co., 484 F.2d 438 (5th Gir. 1973) (refusing to sell homes to blacks and discriminating against blacks in terms and conditions of sale violates Title VIII regardless of intent), cert. denied, 416 U.S. 936 (1974).

84. See supra note 65 and accompanying text.

85. 42 U.S.C. $\$ 3604$ (c) (1982).

86. G. Dyer, Advertising as Communicating 96 (1982). 
sponses." and advertising experts readily acknowledge, that an advertiser's choice of a model's race, as well as other important personal characteristics such as sex and age, is rarely accidental. ${ }^{88}$ The construction of advertisements depicting white models with whom consumers will identify might create an inference that advertisers intentionally seek to appeal to one racial group.

While it might seem that advertisers' motives when designing these ads may be unobjectionable and might simply reflect the fact that there are more white households than non-white households, ${ }^{88}$ such advertising must be considered in the historical context in which it developed. White models have been used in housing advertisements in conjunction with more explicit techniques of indicating a racial preference. From the late nineteenth century until the 1960 s, newspapers listed a separate "Colored" section at the end of each category of real estate advertisements in the classified columns. ${ }^{90}$ Newspapers continued to print advertisements with explicitly stated preferences like "white only" home ${ }^{91}$ into the early 1970s. As these more explicit techniques were abandoned, housing advertisers began relying on subtle word and picture cues which had the effect of signalling to both whites and blacks to whom the housing was open. ${ }^{92}$ In sum:

[C]urrent advertising practices must be examined in light of the historical legacy of segregation and discrimination that have dominated the field of housing in all but the past few years of our nation's history. This is particularly necessary if one is to appreciate the effect of housing advertising on the minority market. Pictures, words, and phrases that were almost assuredly used with a discriminatory intent in housing ads ten or twenty years ago . . . are likely to con-

87. S. Britt, Psychological Principles of Marketing and Consumer Behavior 161 (1978) (citing S. Baker, Visual Persuasion (1961)). The effect of advertisements on consumer decisions is the subject of some debate. While Britt argues that consumers respond to advertisements and millions of dollars are spent each year based on this premise, others such as Michael Schudson claim that advertisements do not control people's choices and that an advertisement's effectiveness is influenced significantly by the context within which it is shown. See M. Schudson, Advertising: The Uneasy Persuasion (1984).

88. The district court in Saunders recognized this fact:

It requires no expert to recognize that human models in advertising attempt to create an identification between the model, the consumer, and the product. In other words, advertisers choose models with whom the targeted consumers will positively identify, hoping to convey the message that people like the depicted models consume and enjoy the advertised product. Therefore, if the consumer wants to emulate the model, he or she will use the product, too.

659 F. Supp. at 1058.

89. The latest data indicate that there are 76,576,000 white households in the United States, compared to 9,797,000 black households. Bureau of the Census, Dep't of Commerce, 1988 Statistical Abstract of the United States 44.

90. See C. Rende, Fair Housing: Unfair Advertising 18-19 (1977).

91. See supra notes 60-62 and accompanying text.

92. C. Rende, supra note 90, at 19 (citing G. Grier, Bias In NewsPaper Real. Estate AdVERTISING (1971)). 
tinue to have that effect today, and for many years to come, even though the intent of advertisers may no longer be the same. ${ }^{33}$

The success of litigation challenging the nearly exclusive use of white models may depend upon showing that this advertising practice is designed to persuade consumers who identify with the models portrayed or to dissuade those who do not identify with the models. If only white models are used in a series of real estate advertisements, potential black tenants may interpret the advertisements to say that only white tenants, like those portrayed, are welcome. Several studies indicate that the current portrayal of blacks in advertisements convey similar messages and thereby promote discriminatory stereotypes of these groups. ${ }^{94}$ Both of the plaintiff's expert witnesses who testified in Saunders provided additional evidence based on academic and market research that black readers interpreted these advertisements to indicate a preference for white tenants. ${ }^{95}$ The available data support the conclusion of the HUD regulations ${ }^{86}$ that the failure to use models "reasonably representing majority and minority groups in a metropolitan area" indicates to the general public that the housing is not "open to all without regard to race, color, religion, sex or national origin." ${ }^{\text {" Th }}$ The federal courts should follow Saunders" lead in recognizing the discriminatory message of these advertisements to black and other readers.

\section{F. The "Deterrent Effect" of Discriminatory Advertisements}

The discriminatory nature of advertisements depicting virtually all white models is consonant with the wide range of behavior that the courts have come to recognize as discriminatory. ${ }^{98}$ For example, in employment

93. Id. See also United States v. Long, Eq. Opportunity in Hous. Rep. (P-H) I 13,631 at 14,089, (D.S.C. 1974) (court focused on context in which reader would understand challenged real estate advertisements and held phrase "any qualified buyer" violated $\$ 3604(\mathrm{c})$ because it was "apparently used in Charleston to alert readers that the advertised properties were available to blacks . . ."), remanded on other grounds, 537 F.2d 1151 (5th Cir. 1975), cert. denied, 429 U.S. 871 (1976).

94. See D. Aaker \& J. Meyers, Advertising Management 503-04 (2d ed. 1982).

95. 659 F. Supp. at 1058 .

96. See supra notes $19-28$ and accompanying text.

97. See supra note 26 and accompanying text.

98. One area where courts have expanded the definition of discriminatory harm has been in recognizing the discriminatory impact on black Americans of certain symbols. See Melton v. Young, 465 F.2d 1332 (6th Cir. 1972) (student suspended for wearing Confederate flag patch), cert. denied, 411 U.S. 951 (1973); Smith v. St. Tammany Parish School Bd., 316 F. Supp. 1174 (E.D. La. 1970) (all Confederate flags must be removed from schools since such symbols indicate racial prejudices), affd, 448 F.2d 414 (5th Cir. 1971). Similarly, courts have interpreted Title VII's language broadly to prohibit another complex form of discrimination, namely the creation of a discriminatory or "hostile" work environment. See Rogers v. Equal Employment Opportunity Comm'n, 454 F.2d 234 (5th Cir. 1971) (per Goldberg, J., with one Circuit Judge concurring in the result), cert. denied, 406 U.S. 957 (1972) (Title VII's phrase "terms, conditions, or privileges of employment" is an expansive concept which prohibits creation of discriminatory work environment); Gray v. Greyhound Lines, E., 545 F.2d 169, 176 (D.C. Cir. 1976) (citing Rogers and holding that pattern of hiring, promoting and soliciting black employees created discriminatory work environment in violation of Title VII), cert. 
discrimination litigation, the Supreme Court has explicitly stated that people deterred from applying for jobs by discriminatory employment practices are as much "victim[s] of discrimination as is he who goes through the motions of submitting an application." ${ }^{\text {"S9 }}$ Similarly, the Fourth Circuit has recognized the deterrent effect discriminatory practices may have in housing, holding that an inference of discrimination can arise even if no blacks have applied for the housing. "[S]eeing large numbers of 'white only' advertisements in one part of a city may deter non-whites from venturing to seek homes there . . .."100

The exclusion of black models from real estate advertisements might also deter blacks from even applying to buy or rent property. The court in Saunders recognized that while advertisers deliberately choose models with whom targeted consumers will identify, these same advertisements may have a deterrent effect on others:

[I]t is natural that readers of the Lifestyle brochure would look at the human models depicted as representing the kinds of individuals that live in and enjoy GSG apartment complexes. If a prospective tenant positively identified with the models, the message conveyed would be that "I belong in these apartments. 'My kind of people' live there." Gonversely, if the prospective tenant reading the brochure saw no models with whom he or she could identify, the reader would obtain a message that "these apartments are not for me or 'my kind." "101

Even though these tenants may never have actually applied for the housing in question, they are clearly victims of the discriminatory advertising practice.

\section{The Problem of Proof}

Although the Fair Housing Act was enacted twenty years ago, the federal courts have rarely been asked to resolve section 3604(c) claims. Types of advertisements previously held to be prohibited under section 3604 (c) include a newspaper advertisement offering for rent a furnished apartment in what was described as a "white only" home, ${ }^{102}$ a newspaper advertisement indicating a preference for tenants who spoke a specific language, ${ }^{103}$ statements by a managing agent to tenants that blacks are not permitted on the premises and cannot be entertained as guests, ${ }^{104}$ and a

denied, 434 U.S. 819 (1977). See also Meritor Sav. Bank v. Vinson, 477 U.S. 57, 66 (1986) (citing Rogers and validating Title VII hostile work environment claim in context of sexual harassment).

99. Teamsters v. United States, 431 U.S. 324, 366 (1977).

100. United States v. Hunter, 459 F.2d 205, 214 (4th Cir.), cert. denied, 409 U.S. 934 (1972).

101. 659 F. Supp. at 1058 . Similarly, when advertisements portray elderly models only, many people assume the housing depicted is senior citizen housing.

102. See supra notes $60-63$ and accompanying text.

103. Holmgren v. Little Village Community Reporter, 342 F. Supp. 512 (N.D. IIl. 1971).

104. United States v. L \& H Land Corp., 407 F. Supp. 576 (S.D. Fla. 1976). 
landlord's oral statement to a current white tenant who was soliciting prospective tenants for her apartment to "make sure her friends were . white."105

These decisions all reflect the traditional methods of discrimination in housing advertisements: The advertisements or statements explicitly indicate a racial preference and therefore violate the statute. The virtual preclusion of non-white models may not be perceived initially as discriminatory because these advertisements do not in so many words exclude prospective black tenants or purchasers. Nonetheless, the practice may be discriminatory because it may "indicate a racial preference" to potential black tenants in the same way as the prohibited practices described above.

Nevertheless, a challenge to the use of human models in real estate advertisements presents unique problems of determining whether the advertisements "indicate a racial preference," problems that an advertisement stating "whites only" does not. The court's decision in Colonial Village, for example, focused on "the problem of the practical ramifications of their claims were these to be sustained." ${ }^{" 106}$ If this judicial wariness is to be overcome, it must be determined exactly which advertisements depicting human models are prohibited by the statute, and what constitutes proof of the discriminatory message of these advertisements.

\section{A. The Number and Nature of the Challenged Real Estate Advertisements}

Because of the unique nature of the alleged discriminatory practice, one question that must be considered in these cases is how many suspect advertisements a plaintiff must refer to in order to establish a section 3604(c) claim. In Colonial Village and Saunders, the plaintiffs challenged the exclusive use of white models in a series of advertisements and throughout a brochure; the plaintiffs did not contend that the presence of exclusively white models in isolated advertisements constituted a violation. The reason for requiring an advertising campaign or brochure rather than isolated advertisements reflects the uniqueness of the problem presented by these cases. As the court in Colonial Village noted, one advertisement featuring only white models may be used without creating a legal inference that the advertisement intends to exclude or has an exclusionary effect. ${ }^{107}$ The opposite legal inference could make advertisements with human models impractical, since every advertisment would have to include numerous models to represent each minority group in the community to avoid violating the statute. ${ }^{108}$ The real question, however, is how

105. United States v. Gilman, 341 F. Supp. 891 (S.D.N.Y. 1972).

106. 662 F. Supp. at 545.

107. Id. at 545 n.7.

108. Id. at 545 . 
many models must be depicted before there is a sufficient number to determine that blacks are indeed not being portrayed in any meaningful number. Gourts need not fear being confronted with endless challenges to individual advertisements if plaintiffs are required to allege a series of discriminatory advertisements or a single publication with a significant number of models. ${ }^{109}$

Another issue raised by these new discrimination claims concerns whether complete or virtual exclusion of black models from these advertising campaigns must be demonstrated to establish a violation. Obviously, the complete exclusion of black models is not required. As the court's decision in Saunders indicates, the inclusion of a few black models in the brochure did not alter the fact that the overwhelming paucity of black models indicated a racial preference and had a deterrent effect. ${ }^{110}$ In addition, if complete exclusion were required, advertisers could easily avoid the reach of the statute by using a token black model in one picture in every brochure or campaign regardless of the ultimate effect of the entire brochure or campaign on prospective black tenants. Instead, the appropriate standard should be the one specified in the HUD regulations: The human models depicted must be "clearly definable as reasonably representing majority and minority groups in a metropolitan area."111

These new cases present another similar issue, namely whether a series of advertisements that includes other racial groups but no blacks, or exclusively depicts black models, violates section 3604(c). Again, the HUD regulations discussed previously ${ }^{112}$ indicate a possible answer to this question: If models are used, they should reasonably represent the majority and minority groups in a metropolitan area, whatever those groups are in a given community, to indicate that the housing is not open solely to one group. While the courts in both Colonial Village and Saunders rejected the argument that the regulations or statute requires that black models be used in strict proportion to their presence in the metropolitan area, ${ }^{113}$ the regulations do suggest guidelines to be followed.

109. Requiring that discriminatory advertisements occur in a significant number to be actionable raises the question of how many advertisements constitute such a number. The courts may have difficulty defining this number in situations in which an advertiser has decided to run occasional advertisements to solicit tenants. However, real estate advertisements frequently occur either in the form of a brochure (as in Saunders) or as part of a general advertising campaign spanning several weeks (as in Colonial Village). In these circumstances, the nature of the advertising arrangement will allow the courts to determine a statutory violation with relative ease.

110. 659 F. Supp. at 1058-59.

111. See supra notes $24-28$ and accompanying text.

112. Id.

113. 662 F. Supp. at 544; 659 F. Supp. at 1060 . 


\section{B. The Difficulties of Statistical Proof}

If a plaintiff does allege the virtual exclusion of black models from a series of advertisements, a further problem remains: She must still convince the court that the advertisements "indicate a racial preference." For example, proof of the discriminatory nature of such advertisements does not lend itself to statistical analysis. Statistics showing the number of black residents in an apartment complex may or may not be related to that development's advertising practices. In addition, it is practically impossible to gather information from every black reader of these advertisements who did not apply as a result. The court in Saunders acknowledged some of these methodological and statistical problems in its assessment of the expert testimony offered in the case. ${ }^{114}$ Perhaps in light of these difficulties, no court that has considered a section 3604(c) claim has invoked a standard of statistical proof. Instead, these courts, particularly the Fourth Circuit in Hunter and the district court in Saunders, have applied a standard more suitable to the language and terms of section $3604(c)$, the ordinary reader standard.

\section{G. The Ordinary Reader Standard}

The Fourth Circuit's opinion in Hunter set forth a clear standard by which advertisements challenged under section 3604(c) should be evaluated. According to that decision, a violation of section 3604(c) is proven if "[t]o the ordinary reader the natural interpretation of the advertisements published . . . is that they indicate a racial preference in the acceptance of tenants." 115 In Hunter, the court held that an ordinary reader would naturally interpret the advertisements to indicate a racial preference. ${ }^{118}$ In Saunders, the court applied this test and found that to the ordinary reader, the natural interpretation of the challenged advertisements was that they indicated a preference for white tenants. ${ }^{117}$

The ordinary reader standard adopted by the Fourth Circuit and the District Court in Virginia is in accord with the broad congressional objective underlying the Fair Housing Act. The standard recognizes the difficulty of obtaining statistical proof from readers and instead asks the court (or the jury, since such ordinary person standards are usually factual standards applied by the trier of fact) ${ }^{\mathbf{1 1 8}}$ to determine how ordinary readers might naturally have interpreted these advertisements. To require more

114. 659 F. Supp. at 1058.

115. Hunter, 459 F.2d at 215.

116. The Fourth Circuit also stated that a natural interpretation of the advertisements would lead the ordinary reader to conclude that the writer of the advertisements intended to indicate a racial limitation. Id. at 215.

117. 659 F. Supp. at 1058.

118. For a discussion of ordinary person (or "reasonable man") standards, see W. Prosser \& W. KeAton, The LAW OF TORTS $\$ \S 32-33$ (5th ed. 1984). 
would undermine the congressional objective of eliminating racial discrimination in housing, since statistical evidence of the effects of advertisements is virtually impossible to gather, and the discriminatory intent of advertisers and developers is often impossible to discern. It seems implausible to suggest that Congress intended to require a burden of proof that would severely limit the scope of this provision, especially in light of Congress' broadly stated objective and the HUD regulations which accompanied the legislation. ${ }^{119}$ If a plaintiff can show that an ordinary reader would naturally interpret the advertisements to indicate a racial preference, the plaintiff has proven a violation of the provision.

Clearly, the ordinary reader standard poses many problems of its own. The standard does not give an exact measure of discriminatory effect, and raises obvious questions: Who is the ordinary reader? What is a natural interpretation of an advertisement? But such questions are not unfamiliar to courts and juries who often apply this type of standard to evaluate how an ordinary person would act in a particular situation. ${ }^{120}$ These questions involve the innate subjectivity of determining what "indicates a racial preference" to whom, and will arise whenever an "ordinary person" or "natural interpretation" standard is used. ${ }^{121}$ Few judicial standards are without ambiguities. Nonetheless, the ordinary reader standard offers a necessary alternative to statistical proof and represents a feasible means of evaluating allegedly discriminatory advertisements.

\section{Conclusion}

The use of virtually all-white models in housing advertisments is a vestige of a long history of housing discrimination through advertising. In increasing numbers, federal courts are being asked to consider claims that these advertisements violate section 3604(c) of the Fair Housing Act. Unlike previous section 3604 (c) decisions, these suits challenge a pictorial advertising technique. Nonetheless, this advertising practice, like the more explicit discriminatory practices previously outlawed, conveys a message to potential non-white tenants that they are not welcome at the advertised housing. The courts should recognize that the messages conveyed by these

119. See supra notes $26-37$ and accompanying text.

120. In the area of defamation law, for example, judges and juries are frequently asked to determine how an ordinary reader would interpret a given publication. See Restatement (SECOND) of ToRTs $\S 563$ comment c (1976) ("In determining the reasonableness of the recipient's understanding, that meaning is to be given to words which is ordinarily attached to them by persons familiar with the language used.").

121. This question becomes especially difficult in the context of discrimination. Professor Minow has argued that "difference" makes it difficult for dominant groups to appreciate the legal claims of others and urges judges to recognize their own biases and adopt different perspectives. This provides an additional reason why the ordinary black reader's discriminatory interpretation should be sufficient to show a violation, although such advertisements may also, of course, seem equally discriminatory to a white reader. See Minow, The Supreme Court, 1986 Term-Foreward: Justice Endangered, 101 Harv. L. Rev. 10 (1987). 
series of all-white advertisements reinforce discriminatory housing patterns.

Less explicit forms of discrimination, however, may present different problems of proof. The statutory language of section 3604(c) and the legislative history of Title VIII both suggest that Congress recognized the difficulty of proving an intent to discriminate in certain situations and sought to establish a burden of proof that did not require a demonstration of discriminatory purpose. The federal courts have adopted a broad reading of Title VIII and have held that no showing of discriminatory purpose is required to prove a violation of the Act. The same legal standard should govern these new section 3604(c) claims.

Plaintiffs still must prove the discriminatory nature of these humanmodel advertisements. While minority underrepresentation and disparate impact standards have been used in many cases, these standards of proof have not been and should not be applied to section 3604(c) claims. Instead, the federal courts should apply the ordinary reader test to section 3604(c) claims, including those now being brought to challenge the use of virtually all-white models in real estate advertisements. If the discriminatory nature of these ads is properly recognized and the appropriate standard of proof is applied, future plaintiffs will be successful in eradicating this discriminatory advertising practice. 
